\title{
DEBT AND TAXES
}

\author{
David Hasen*
}

\begin{abstract}
The federal income tax conceptualizes the standard loan transaction as an exchange of cash for promises to pay interest and to repay the amount borrowed by the end of the term. This formulation is subtly incorrect in ways that have led to a weaker foundation for existing tax rules than they merit. Conceptualizing loans instead as closely akin to leases places most of the tax rules for debt on sounder footing because it clarifies that interest is the consideration paid for the use of the loan proceeds. If interest is the cost of the use of money, then simple borrowing is a fully-paid-for transaction, full basis credit in the loan proceeds for the period for which interest is paid is appropriate, and cancellation of debt is a straightforward accession to wealth in the period in which it occurs. These conclusions hold whether the interest is deductible or not and are consistent with current law, which has come under fire from some quarters.

Although the proposed reconceptualization of loan as lease supports a number of longstanding income tax rules, one area in which it counsels significant reform is the taxation of partnerships. If loans are like cash leases made in exchange for interest qualifying as rent, Treasury should provide for the allocation of basis credit among partners for the partnership's debt based on who bears the economic burden of the interest expense. The rule should apply regardless of whether the debt is recourse or nonrecourse and regardless of who would have discharge of indebtedness income on default. Such an approach differs markedly from the existing rules for recourse obligations but is closer to the rules for certain nonrecourse obligations. A modification of the rules applicable to partnership debt consistent with the loan-as-lease theory, therefore, would remove a significant discontinuity in the current tax treatment of partnership debt.
\end{abstract}

I. INTRODUCTION 90

II. THE LOAN TRANSACTION: THE STANDARD VIEW . 93

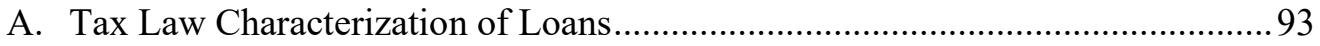

B. Proposition 1: The Extension of the Loan has no Tax Consequences ..................94

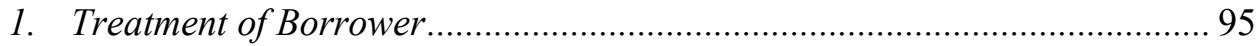

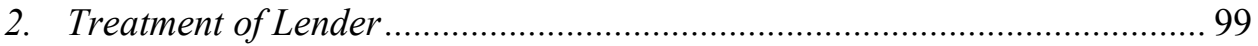

C. Proposition 2: Both Parties Receive Basis Credit.............................................. 99

D. Proposition 3: Borrower Default Triggers an Inclusion................................... 102

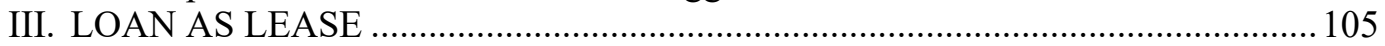

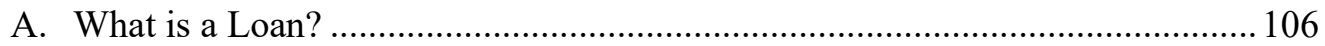

B. What Tax Consequences Follow From LAL? ................................................. 108

C. LAL When the Lender Assumes Risk .................................................................. 109

1. Considering the Risk of Loss as a Partial Receipt of the Fee .................... 110

2. Provision of Security and Covenants ....................................................... 111

\footnotetext{
* Professor, University of Florida Levin College of Law. Thanks to Pat Cain, Charlene Luke, Gregg Polsky, Pierre Schlag, participants at conferences and the editors of the Columbia Journal of Tax Law. I remain solely responsible for all errors.
} 
3. Taxation of DOI 113

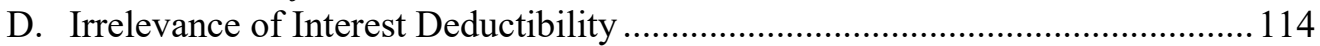

IV. THE TAX TREATMENT OF PARTNERSHIP BORROWING …......................117

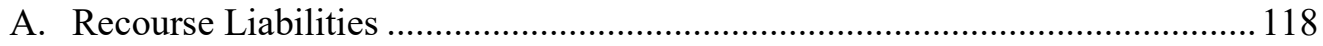

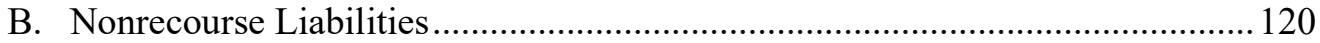

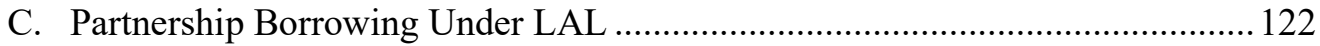

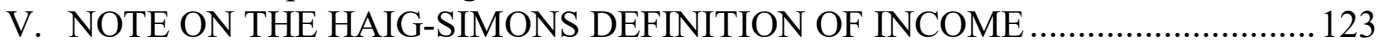

VI. CONCLUSION 125

I.

\section{INTRODUCTION}

Most of the tax rules that apply to loans are settled, but the proper tax treatment of loans has long been in dispute. ${ }^{1}$ This Article argues that the dispute is in large part traceable to an inaccurate account of the loan transaction itself. Under a better account, most of the existing tax rules turn out to be correct. Others require substantial revision.

A loan is commonly understood as the lender's transfer of funds to the borrower on condition that the funds be repaid, with interest due in the interim. ${ }^{2}$ That is, the transaction is framed as a swap of loan proceeds on one hand for promises to pay interest and the amount borrowed back on the other. This formulation in turn serves as the factual substrate to which the income tax analysis of loans applies. That analysis has resulted in the following settled rules: ${ }^{3}$ the transfer of loan proceeds is nontaxable to the borrower and non-deductible to the lender; ${ }^{4}$ the borrower has full basis credit in the loan proceeds, ${ }^{5}$ meaning that no tax arises on the use of the proceeds to purchase property and the borrower has a cost basis in the purchased property; and there is no deduction to the borrower and no inclusion to the lender on repayment. ${ }^{6}$ If, however, the debt is canceled, the borrower

${ }^{1}$ Many articles have been written about whether the income tax rules for the treatment of the extension of a loan and of interest payments are correct. Among the more well-known are Charlotte Crane, Liabilities and the Need to Keep the Tax Base Closed, 25 VA. TAX REV. 31 (2005); Joseph M. Dodge, Exploring the Income Tax Treatment of Borrowing and Liabilities, or Why the Accrual Method Should Be Eliminated, 26 VA. TAX Rev. 245 (2006); Deborah A. Geier, Tufts and the Evolution of Discharge Theory, 1 Fla. TAX ReV. 115 (1992); Martin J. McMahon, Jr. \& Daniel L. Simmons, A Field Guide to Cancellation of Debt Income, 63 TAx L. 415 (2010); Daniel N. Shaviro, Risk and Accrual; The Tax Treatment of Nonrecourse Debt, 44 TAX L. REV. 401 (1989); Patricia D. White, Realization, Recognition, Reconciliation, Rationality and the Structure of the Federal Income Tax System, 88 Mich. L. REV. 2034 (1990). As will become clear from the discussion, most of the controversy is resolved under the proposal developed here, which focuses less on the tax rules than on the economics of the basic borrowing transaction.

${ }^{2}$ One well-known casebook describes the basic loan transaction as follows: "[I]n a classic debt instrument, the lender transfers money to (or on behalf of) the borrower at the start of the associated loan transaction. The borrower is expected to repay the amount borrowed (i.e., the loan principal) at the end of the transaction.” JoSEPH BANKMAN ET AL., FEDERAL InCOME TAXATION 317 (18th ed. 2019).

${ }^{3}$ For a general discussion of the income tax treatment of borrowing, see, e.g., BORIS I. BITTKER \& LaWrence LoKken, Federal TaXation of Income, Estates, and GifTs, $\boldsymbol{q} 7.1$.

${ }^{4}$ Non-inclusion of loan proceeds in gross income is not specifically provided for in the Internal Revenue Code, but loans have always been so treated. See, e.g., McMahon \& Simmons, supra note 1, at 417 ("As a fundamental principle of tax, borrowed funds are excluded from gross income because the obligation to repay borrowed funds offsets the economic increment even though borrowed funds increase a taxpayer's assets and can be used as the taxpayer sees fit.").

${ }^{5}$ See, e.g., Comm'r v. Tufts, 461 U.S. 300 (1983), for a statement of the rule.

${ }^{6} I d$. at 307 . 
has income from the discharge of indebtedness, ${ }^{7}$ or in some instances, gain or loss from the sale or exchange of property, ${ }^{8}$ while the lender has either a worthless security deduction or a bad debt deduction. ${ }^{9}$

Although these rules are settled, they are controversial. The common justification for the treatment of the borrower is that the repayment obligation precisely offsets the value of the funds received. ${ }^{10}$ The return obligation in turn is said to imply that the arrangement has a net zero value, so that the extension of the loan does not enrich the borrower. In the language of income tax policy, the borrower is not taxed because there has been no "accession to wealth." 11 In corresponding fashion, the repayment of the loan reduces the obligation dollar for dollar so that no deduction is appropriate when the loan is repaid. ${ }^{12}$ On the lender side, the receipt of the borrower's note in exchange for the proceeds is a simple cash purchase so that the lender likewise realizes no gain or loss. ${ }^{13}$ And, analogously to the borrower, amounts that the lender receives as principal repayments reduce the lender's right to further payments dollar for dollar so that no income arises on repayment either.

In response, critics have noted that the income tax is normally triggered without a requirement of receipt of value; rather, tax is due when untaxed value is exchanged for property, ${ }^{14}$ and sometimes even before the exchange takes place. ${ }^{15}$ Moreover, when exchanges are not taxed, a special basis regime normally applies to ensure that tax is merely deferred rather than eliminated. ${ }^{16}$ No such basis regime exists for loans. Similarly, it is not obvious that the lender suffers no loss on transfer of the loan proceeds since the lender has lost use of the funds during the loan term and has placed the funds at risk.

This Article argues that the tax rules described above are nearly correct but the justifications for them are not because they rest on a faulty understanding of the economic substance of the loan transaction. A loan is not a swap of the loan proceeds for the obligation to return them plus interest. This description mistakes the physical events that occur in consequence of the loan agreement for the legal relations that the loan agreement

${ }^{7}$ I.R.C. $\S 61(a)(12)$. Section 108 goes on to provide circumstances in which the income is excluded based on various policy grounds generally unrelated to whether the taxpayer has economic income by reason of the discharge.

${ }^{8}$ This is the rule when the borrower satisfies nonrecourse debt by transferring to the lender the property used as security for the loan. Crane v. Comm'r, 331 U.S. 1 (1940).

${ }^{9}$ I.R.C. $\$ 165(\mathrm{~g})$ (capital loss deduction on worthless securities); I.R.C. $§ 166$ (a) (bad debt deduction on other debt instruments, the character of which depends on whether the debt is business or non-business in nature).

${ }^{10}$ See generally the authorities cited supra note 1. See infra Part II.A for a discussion of debates in the income tax literature on the proper tax treatment of the loan so conceived.

11 The authorities and commentary are numerous. Among the notable ones are Comm'r v. Tufts, 461 U.S. 300, 307 (1983) ("When a taxpayer receives a loan, he incurs an obligation to repay that loan at some future date. Because of this obligation, the loan proceeds do not qualify as income to the taxpayer. When he fulfills the obligation, the repayment of the loan likewise has no effect on his tax liability."); BITTKER \& LOKKEN, supra note 3, 7.1 ("Borrowed funds are excluded from gross income, even though they increase the taxpayer's assets and can be used as the taxpayer sees fit, because the obligation to repay increases the taxpayer's liabilities by the same amount and the loan therefore produces no gain.”) (citing commentary).

${ }^{12}$ See infra Part II.A. for further discussion of this topic.

${ }^{13}$ I.R.C. $\S 1001(a)$.

${ }^{14}$ See infra Part II.B. for further discussion of this topic.

${ }^{15}$ Am. Auto. Ass'n v. U.S., 367 U.S. 687 (1961).

${ }^{16}$ E.g., I.R.C. $\$ 358$ (a) (exchanged basis in certain corporate formations and reorganizations); I.R.C. $\S 722$ (exchanged basis in partnership formations); I.R.C. § 1031(d) (exchanged basis in like-kind exchanges). 
establishes. ${ }^{17}$ Rather, a loan is simply the purchase of the use of funds during the loan term, together, in most cases, with further legal incidents that relate to the risk assumed by the lender. So conceived, a loan is analogous, though not identical, to a lease. Under a lease, the physical transfer of the subject property does not signify a change in ownership of the fee interest; instead, the physical transfer of the subject property is incidental to the legal entitlement purchased (as is its retransfer at the end of the lease), which is the use of the subject property during the lease term. Similarly, the physical transfer of funds pursuant to a loan agreement does not signify that the funds themselves have legally changed hands. Instead, the lender has sold a time-slice of the funds to the borrower. Thus, disregarding for the moment the risk of loss that attends most loan transactions, it follows that the borrower obtains no right to or interest in the proceeds beyond the loan term.

In consequence, the "remainder" is not transferred to the borrower in the first place, nor transferred back in the second. It follows further that the consideration for the loan is interest, not interest plus an obligation to return. The remainder is along for the ride, but just as the remainder in a lease arrangement is not part of the parties' bargain, the remainder of the funds lent - their use for all periods following the loan term - is not bargained-for consideration. The value-for-value exchange for the use of the funds - the "rent"-is, correspondingly, not an obligation to return but instead what is denominated "interest." Because the payment of interest is an ongoing obligation that reflects an arm's-length cash purchase, the tax consequences of borrowing are straightforward: no income on receipt of the loan proceeds, no deduction on repayment, and full basis credit in the funds borrowed as long as interest payments remain current.

Things become somewhat more complicated once one incorporates risk of default into the equation, but the basic analysis does not change. The presence of default risk means that what is called "interest" pays for more than the right to use the funds during the loan term. It also covers the possibility that the incidental transfer of the remainder will not be reversed. In this respect, the deal is more than payment in exchange for use. It is payment for use plus payment for a form of insurance against a certain kind of risk of loss. Nevertheless, the borrower continues to pay for that risk on the same ongoing basis that the borrower pays for the use, not through an additional promise to retransfer the loan proceeds at the term. Instead, the nominal interest payment is larger to reflect the insurance purchased; it includes what is commonly termed a risk premium. ${ }^{18}$ In addition, there may be other forms of "payment" from the borrower, such as restrictions on borrower activity, the right of the lender to monitor the borrower, the provision of security, or some combination of these. Like an interest payment or a risk premium, however, these payments are made contemporaneously and generally do not trigger gain or loss to either party.

Misconceptions about the nature of borrowing create casualties beyond their threat to destabilize the current regime. They include obscuring the proper understanding of the

${ }^{17}$ As will become clear, the analysis is sympathetic to Hohfeld's critique of the analysis of "rights." Among Hohfeld's criticisms was that analysts often confuse the physical events attendant to the legal relations with the relations themselves. Wesley Newcomb Hohfeld, Some Fundamental Legal Conceptions as Applied in Judicial Reasoning, 23 YALE L.J. 16, 24 (1913).

18 For a standard statement of the principle, see Default Risk Premium, https:// corporatefinanceinstitute.com/resources/knowledge/finance/default-risk-premium/ $\quad[\mathrm{https} / /$ perma.cc/B7WXKMGA] (last visited Mar. 21, 2021) ("A default risk premium is effectively the difference between a debt instrument's interest rate and the risk-free rate. The default risk premium exists to compensate investors for an entity's likelihood of defaulting on their [sic] debt."). 
nature of income from the discharge of indebtedness (DOI), of the differences between recourse and nonrecourse debt, and even of the relative merits of income and consumption as tax bases. Stated more positively, a better theory of debt would be of significant value in the effort to tax it properly and, conversely, in any effort to implement consumption tax principles to a greater extent than the law currently does, should Congress move in that direction. Perhaps most significantly as a doctrinal matter, the argument counsels a wholesale revision of the tax rules for partnerships' allocation of basis credit among the partners when the partnership borrows. ${ }^{19}$

Part II of this Article describes the received view of the loan transaction and reviews both its tax treatment and the conceptual problems that commentators have identified with that treatment. Part III develops the case for understanding loans as analogous to lease transactions and, consequently, for understanding interest or interest plus insurance as the exclusive consideration that the borrower pays in a standard loan. It then shows that the loan-as-lease view (LAL) solves the problems raised in Part II. A final subpart rebuts the argument that the tax treatment of loan proceeds ought to hinge on whether interest is deductible; it shows that the deductibility of interest has no bearing on the tax treatment of loan proceeds under LAL. Part IV discusses the tax treatment of loans in the partnership setting, which is one area in which adoption of LAL would have significant ramifications for current law. Part V briefly discusses some of the implications of LAL for understanding the nature of and differences between income and consumption as tax bases.

\section{THE LOAN TRANSACTION: THE STANDARD VIEW}

In the simplest loan transaction, the borrower receives cash from the lender in exchange for promises to pay interest periodically at a fixed rate during the loan term, and to pay the same amount of cash back to the lender at the end of the term. ${ }^{20}$ The tax law generally follows this characterization, ${ }^{21}$ which will be referred to as the "standard view." The central feature of the standard view is its conceptualization of the loan transaction as the exchange of a fee interest in cash on one hand for promises to pay interest and a return of the fee on the other.

\section{A. Tax Law Characterization of Loans}

The standard view underlies the analysis of the tax treatment of the loan transaction, which has yielded the following rules: ${ }^{22}$

1. The borrower has no income on receipt of the loan proceeds and no deduction on their repayment. Correlatively, the lender has no deduction and no inclusion. ${ }^{23}$

19 These rules are provided in section 752 and the regulations thereunder. Partnership loan accounting is discussed in some detail in infra Part IV.

${ }^{20}$ For a definition of "loan,” see, e.g., Technicorp Int'l II, Inc., and Statek Corp. v. Johnston, et al. 1997 WL 538671, *21 (Del. Chancery Ct. 1997) ("By definition a loan is "something lent or furnished on condition of being returned, esp[ecially] a sum of money lent at interest." (citing Random House College Dictionary (1975) (emphases and brackets in court opinion)). Proposed regulations under section 7872 define a loan to include "any transaction under which the owner of money permits another person to use the money for a period of time after which the money is to be transferred to the owner or applied according to an express or implied agreement with the owner.” Prop. Reg. § 1.7872-2(a)(1) (1985).

${ }^{21}$ BITTKER \& LOKKEN, supra note 3 , 97.1 .

${ }^{22} I d$.

${ }^{23}$ The rule applies only to the loan proceeds themselves, not to interest or other costs incurred in connection with the borrowing, which may be deductible in full or part by the borrower and are almost always 
2. The borrower has full basis credit in the loan proceeds (and the lender has full basis in the note purchased with the loan proceeds), meaning in the case of the borrower that the use of loan proceeds provides the borrower with a cost basis in purchased property even though no tax is due on that purchase. The lender similarly applies basis to offset the amount received if she disposes of the note.

3. Cancellation of the loan because it is uncollectible is a taxable event to the borrower and (typically) generates a bad debt deduction to the lender equal in amount to the debt forgiven. ${ }^{24}$ The treatment of the taxable event depends on whether or not the debt was recourse or nonrecourse:

a. In the case of "recourse" debt, the borrower's inclusion is treated as ordinary income resulting from DOI. ${ }^{25}$

b. In the case of "nonrecourse" debt, any inclusion or deduction for the borrower is treated as resulting from the sale or exchange of property if the debtor uses the property to satisfy the loan. ${ }^{26}$ Otherwise, the cancellation is treated the same as a cancellation of recourse debt. ${ }^{27}$

Nearly all commentators agree with the standard view, but many disagree that the resulting three propositions are correct as a matter of income taxation-at least in its ideal form. As it happens, the propositions are mostly right, but they are understood as right for reasons that are vulnerable to criticism (and confusion) because the conceptualization of the debt transaction to which they apply - that is, the standard view-is wrong. The voluminous commentary on how debt "should" be taxed under a normative income tax attests to the vulnerability. The rest of this Part illustrates the point through an exploration of some of the controversies that have arisen regarding the tax treatment of loan transactions under the standard view, as well as the basic arguments for and against that treatment that commentators have raised. As will become evident, the standard view does not unambiguously support the tax rules that have long been in effect.

\section{B. Proposition 1: The Extension of the Loan has no Tax Consequences}

The starting point for an analysis of the proper treatment of the transfer of loan proceeds under an ideal, or normative, income tax is the definition of income. A normative income tax is generally understood to impose a burden on "accessions to wealth" during the taxable period. The canonical formulation is the so-called Haig-Simons (H-S) definition: "Personal income may be defined as the algebraic sum of (1) the market value of rights exercised in consumption and (2) the change in the value of the store of property rights between the beginning and end of the period in question." 28

includible by the lender. See I.R.C. $\S 163$ (deduction for interest expense, subject to limitations); I.R.C. $\S 61(a)(4)$ (interest is an item of gross income).

${ }^{24}$ On the borrower side, the applicable provisions are section 61(a)(12) (inclusion of income from DOI in gross income in the case of recourse debts) or sections 1001(a) and 7701(g) (gain (or potentially loss) from sale of property, treating amount realized as not less than outstanding principal amount under section $7701(\mathrm{~g})$ ). On the lender side, the applicable provisions are section 165(g) (deduction for loss on worthless securities) or section 166(a) (deduction for bad debts). Very generally, the lender's loss is deductible under section $165(\mathrm{~g})$ if the debt is publicly traded but deductible under section 166 in most other cases.

${ }^{25}$ Treas. Reg. $\S 1.1001-2$.

${ }^{26}$ Comm'r v. Tufts, 461 U.S. 300 (1983).

${ }^{27}$ Rev. Rul. 91-31, 1991-1 C.B. 19; Gershkowitz v. Comm'r, 88 T.C. 984 (1987).

${ }^{28}$ Henry Simons, Personal Income Taxation 50 (1938). Countless commentaries use this definition, the so-called "Haig-Simons" or "Schanz-Haig-Simons" definition, for the purpose of defining income under a normative or ideal income tax. See William D. Andrews, Personal Deductions in an Ideal 


\section{Treatment of Borrower}

Under the H-S definition, Proposition 1 is said to follow on the borrower side because the obligation to repay, when coupled with the obligation to pay interest on the outstanding principal, precisely offsets the value of cash received. ${ }^{29}$ Similarly, as amounts are repaid, the concomitant reduction in the repayment obligation implies that no deduction for the payments is appropriate - the borrower does not experience a loss on the payments because she receives an equally valuable reduction in her obligation to repay. Assume Borrower borrows $\$ 1,000$ from Lender, promising to pay a market rate of interest on the full $\$ 1,000$ semiannually for 10 years and to repay the $\$ 1,000$ at the end of the term. On the standard view, Borrower has received $\$ 1,000$ in exchange for promises. Ordinarily the receipt of cash constitutes income to the extent that it exceeds the taxpayer's basis in whatever is surrendered for the cash. ${ }^{30}$ Here, Borrower surrenders nothing except promises in which she has no basis because she has paid no after-tax amount to make them. Nevertheless, the tax law has long taken the view that the obligation to repay the $\$ 1,000$ offsets the receipt so that Borrower has no inclusion. Lender has received a note of value equal to what she transfers to Borrower and, likewise, has no income. On repayment, Borrower's offsetting obligation is lifted, while Lender's note is exchanged for cash of equal value.

The commonly offered rationale for the rule is that because the net market value of the rights received is zero, Borrower in effect has received nothing. ${ }^{31}$ Although she has received value for promises in which she has no basis, the obligation to repay, which will be satisfied with already-taxed dollars, must be netted with the value received to determine how much income she has in the first place. Because the netting yields zero, she has neither income nor loss. The result is to be contrasted with, for example, the sale of property for cash. Suppose that Seller exchanges a painting for which she had paid $\$ 700$ for $\$ 1,000$ cash from Buyer, neither party incurring any further obligation with respect to the other. Here, Seller has received $\$ 1,000$ of value and experienced a net increase in after-tax wealth of $\$ 300$ (equal to the difference in her cost, or basis, in the painting and its fair market value). She has taxable income of $\$ 300$.

The offsetting liability theory has won wide but not universal acceptance in the literature. $^{32}$ One group of commentators has observed that the rules differ markedly in other conceptually similar areas for reasons that are not obvious. For example, subject to limited statutory ${ }^{33}$ and administrative exceptions, ${ }^{34}$ payments received for property or

Income Tax, 86 HARV. L. REV. 309, 320 (1972) (referring to this definition as "the most widely accepted definition of personal income for tax purposes ...").

${ }^{29}$ Some commentators cite merely the requirement to repay the principal as the basis for the rule; others include the requirement to pay interest to account for the time-value of money as the basis for the rule. See, e.g., BITTKER \& LOKKEN, supra note 3, 77.1 (no inclusion because of obligation to repay); Shaviro, supra note 1, at 406 (obligation to repay plus interest justifies non-inclusion); White, supra note 1, at 2072 ("The familiar justification for the rule that loan proceeds are not included in taxable income is that the borrower's obligation to repay offsets the amount borrowed and leaves her net worth unaffected."). It is possible that some commentators view the interest obligation as implicit, treating the statement that the principal must be repaid as shorthand for the additional obligation to pay interest.

${ }^{30}$ I.R.C. $\S 1001(\mathrm{a})$.

${ }^{31}$ BITTKER \& LOKKEN, supra note $3, \uparrow 7.1$.

${ }^{32}$ Proponents include, in addition to authors cited in preceding notes, Deborah Geier and Ethan Yale. See e.g., Geier, supra note 1, at 145-146; Ethan Yale, Anti-Basis, 94 N.C. L. REV. 485, 493 (2016).

${ }^{33}$ I.R.C. $\S 451(\mathrm{c})$.

${ }^{34}$ Rev. Proc. 2004-34, 2004-1 C.B. 911, modified, Rev. Proc. 2011-18, 2011-5 C.B. 441. 
services to be delivered in the future are subject to inclusion on receipt, even when the taxpayer uses an accrual method of accounting. ${ }^{35}$ Under an accrual method, items are normally includible in the period during which the right to the payment is fixed and the amount of the receipt can be determined with reasonable accuracy. ${ }^{36}$ In many advance payment situations, the right to retain the payment is contingent on the provision of future services and therefore not fixed, yet the taxpayer must include on receipt nonetheless. ${ }^{37}$

Another more basic criticism focuses on the fact that taxability generally hinges not on the receipt of net value but on the extent to which the taxpayer has realized value for which she lacks the requisite after-tax investment. In economic terms, arm's-length exchanges involve no income to either party because parties acting at arm's length do not voluntarily part with value; they exchange items (including possibly services) of equal market value, typically because there is private surplus associated with doing so. ${ }^{38}$ Rather, exchanges are taxable if, and to the extent, that a transferor receives value in excess of her already-taxed investment in whatever she has surrendered for that value (and, correspondingly, a deduction if after-tax investment exceeds value received, subject to exceptions). ${ }^{39}$ In the Buyer/Seller example, Seller does not have $\$ 300$ of economic income; that $\$ 300$ of value accrued during her ownership of the asset, before its disposition, a fact that explains why Buyer is willing to part with $\$ 1,000$ for it. Instead, she has zero economic income but $\$ 300$ of taxable income, and this is because of the confluence of two features of the income tax. First, she had only been taxed on $\$ 700$ of the painting's $\$ 1,000$ value before the exchange; and second, under a realization-based tax system, accrued gains are generally taxed on disposition. The sale, as a realization event, sufficed to trigger a tax on the previously untaxed gain in the absence of any special rule that would defer or possibly exempt the gain. ${ }^{40}$

It is hard to see how the loan case differs from a taxable exchange if the standard view is correct. Borrower exchanges promises concededly worth the value of what she receives from Lender; otherwise, Lender would not engage in the transaction. But Borrower has made no after-tax investment in her promises. If what she receives has any value at all, it seems she should be taxed on the receipt (again, under the standard view).

Other critics of the current rules take a softer view, generally on the basis that policy goals other than taxing realized income may justify deferral of tax on receipt of loan proceeds even though the borrower may have income strictly speaking. There are numerous transactions for which Congress has explicitly provided nonrecognition

${ }^{35}$ See, e.g., Schlude v. Comm'r, 372 U.S. 128 (1963) (advance payments for future dance lessons includible on receipt even though the taxpayer used an accrual method). Sections 451(b) and (c) have codified the Schlude rule to some extent.

${ }^{36}$ Treas. Reg. § 1.451-1(a).

${ }^{37}$ Am. Auto. Ass'n v. U.S., 367 U.S. 687 (1961).

${ }^{38}$ The principle is subject to some exceptions not pertinent to the analysis here. For example, a distressed seller may settle for less than fair market value on an exchange, or a thin market may result in a price different from the price that would result if the subject property were of a kind widely traded.

${ }^{39}$ I.R.C. $\S 165$. Note that most losses on personal property are disallowed. See I.R.C. $\S 165(\mathrm{c})$. The general theory of the disallowance is that in most cases the taxpayer has consumed the difference between basis and value through use.

${ }^{40}$ I.R.C. $\$ 1001(\mathrm{a})$. Various nonrecognition provisions apply to defer gain in some cases. These provisions generally reflect non-income tax policy goals. See, e.g., I.R.C. § 102(a) (donee not taxed on receipt of gift); I.R.C. $\S 1031$ (a) (gain or loss realized in a like-kind exchange is not recognized). Less commonly, gain may permanently escape tax. See, e.g., I.R.C. $\S \S 1014($ a), 102(a) (Basis in property received from a decedent is its fair market value at time of death even though no tax arises on death or transfer). 
treatment on policy grounds, and one can argue that loans are just another such case. For example, Anthony Polito argues that under an income tax that is triggered on realization events, there is no a priori reason not to tax the receipt of loan proceeds, inasmuch as the borrower faces no cost in gaining the use of them and their receipt qualifies as a realization event - an exchange of the promises for the cash. ${ }^{41}$ In Polito's view, the tax law could equally treat the receipt as partly taxable or fully taxable, noting that each of these methods applies in different settings as a way to account for the return of capital. ${ }^{42}$ For example, amounts received as returns on corporate stock are treated first as taxable distributions of corporate earnings and only after earnings are exhausted as a return of capital. ${ }^{43}$ A similar rule applies to interest earned on debt instruments. ${ }^{44}$ Amounts paid under installment obligations received in exchange for appreciated property, by contrast, are generally allocated ratably between gain and return of capital. ${ }^{45}$ In the rare cases in which the open transaction doctrine applies, amounts received may be treated as return of capital before any gain is recognized. ${ }^{46}$ Polito considers that any of these regimes could conceivably apply to loans under a realization-based income tax, inasmuch as what motivates the realization rule are considerations of practicality, not the income concept. ${ }^{47}$

As another example, Dan Shaviro notes that borrowing that is secured by property resembles a sale in that the lender may look to the security to satisfy the loan on nonpayment. If the amount of the loan exceeds the borrower's basis in the security, one could argue for a rule that requires gain recognition to the extent of the excess, or perhaps to the extent of some ratable portion of the excess. This argument works because, as a practical matter, the receipt of the loan proceeds ensures that the borrower has liquidated the gain. ${ }^{48}$ Shaviro observes that the rule would seem more appropriate for nonrecourse debt. In a nonrecourse debt arrangement, the lender takes a security interest in one or more of the borrower's assets but has no right to proceed against the borrower in the case of default. ${ }^{49}$ Thus, the borrower incurs literally no obligation to make any payment in excess of the value of the security pledged. If the loan proceeds exceed the borrower's basis in the security (or come to exceed it when basis declines over time, typically because of cost recovery), the borrower has locked in the excess, and the transaction appears to be closely similar to a taxable sale to that extent. ${ }^{50}$ To illustrate, suppose in our earlier example that Borrower's loan was nonrecourse and that Borrower pledged as security for the loan an asset having a basis to borrower of $\$ 200$. The asset is worth $\$ 1,500$. If the value of the

\footnotetext{
${ }^{41}$ Anthony P. Polito, Borrowing, Return of Capital Conventions, and the Structure of the Income Tax: An Essay in Statutory Interpretation, 17 VA. TAX REV. 467, 478 (1998).

${ }^{42} \mathrm{Id}$. at 479. See also BITTKER \& LOKKEN, supra note 3, ๆ 7.1 (grounding the non-inclusion, nondeduction rule in considerations of practicality rather than the nature of income).

${ }^{43}$ I.R.C. $\S 301(\mathrm{c})$

${ }^{44}$ I.R.C. $\S 61(\mathrm{a})(4)$

${ }^{45}$ I.R.C. $\S 453(\mathrm{a})$.

${ }^{46}$ As examples, this rule can apply to a shareholder who receives proceeds from a taxable liquidation of a corporation over more than one taxable year. I.R.C. $\S 331$ (a); Rev. Rul. 85-48, 1985-1 C.B. 126. It also applies to the writer of an option on receipt of the option premium. See Rev. Rul. 78-182, 1978-1 C.B. 265.

${ }^{47}$ See Helvering v. Horst, 311 U.S. 112, 116 (1940).

${ }^{48}$ See Shaviro, supra note 1, at 408. Shaviro concludes that even in this setting, nonrecourse borrowing generally should not trigger gain. $I d$. at 447-48.

49 See Frederick H. Robinson, Nonrecourse Indebtedness, 11 VA. TAX REV. 1, 3 (1991) (" $[\mathrm{N}]$ onrecourse debt is an indebtedness with respect to which the person who has the use of the borrowed funds has no personal liability.”).

${ }^{50} I d$.
} 
asset falls below $\$ 1,000$ (the face amount of the loan) at any point during the loan term, it is rational for Borrower to tender the asset to Lender in satisfaction of the loan. It follows that Borrower has "locked in" $\$ 800$ of gain by entering into the loan arrangement and, one could argue, should be taxed on that gain upon execution of the loan as though the property were deemed sold and repurchased for $\$ 1,000 .^{51}$

As a final example, Joseph Dodge has argued that the non-inclusion rule is incorrect in the context of an income tax based on the realization rule. ${ }^{52}$ As previously noted, under a realization-based income tax, gains and losses with respect to property are not acknowledged prior to the period in which a realization - typically a disposition - of the property takes place. ${ }^{53}$ According to Dodge, in the case of a loan, the receipt of the proceeds is a realization event, but the repayment obligation, which is what offsets or cancels the inclusion, is not. This is because the obligation does not cause the taxpayer to experience a diminution in control over spendable wealth during the tax period (except to the extent the repayment obligation arises in the same tax period). Therefore, in Dodge's view, Borrower should have a $\$ 1,000$ inclusion in Year 1 on the facts above and a $\$ 1,000$ deduction in the year of repayment. Dodge contrasts this analysis with that under an accrual income tax, under which, he argues, the obligation to repay is recognized immediately because it is fixed and determinable, there being no requirement of actual payment to acknowledge the liability. ${ }^{54}$

There are significant problems with Dodge's view, but what is relevant for present purposes is that the controversy between Dodge and those who disagree with him likely cannot be finally settled under the standard view. In an extended reply to his article, Charlotte Crane notes, among other problems, that it is hard to square his analysis with the idea that the recipient of loan proceeds does not appear to have experienced the same increase in wealth that someone who receives a windfall in the same dollar amount does. ${ }^{55}$ We are inclined to say that two otherwise identically situated individuals who each receive $\$ 100,000$ in cash are not equally wealthy if one of them must pay it back in two years while the other has it free and clear. ${ }^{56}$ For Dodge, however, this criticism is presumably beside the point. We can address the problem by eliminating realization as a requirement for tax accounting. Then it becomes possible to account for future obligations. ${ }^{57}$

If one considers periodicity to be essential to an income tax-a debatable proposition, as I argue below ${ }^{58}$ - one might conclude that the difference between Crane's and Dodge's positions boils down to a semantic disagreement over the meaning of "realization." For Dodge it does not include events that occur in future periods even if the occurrence of the event is legally required on the basis of commitments entered into in the current period; for Crane (and most others, it seems) it does. ${ }^{59}$ For them, the realization

${ }^{51}$ The contrary rule that the borrower recognizes no gain on the execution of a nonrecourse loan is settled. See Woodsam Assoc., Inc. v. Comm'r, 198 F.2d 357 (2nd Cir. 1952).

${ }^{52}$ See Dodge, supra note 1, at 256-65.

${ }^{53}$ See I.R.C. $\S 1001(\mathrm{a})$.

${ }^{54}$ See Treas. Reg. § 1.451-1(a).

55 See Charlotte Crane, Loan Proceeds as Income: A Reply to Professor Dodge, 27 VA. TAX REV. 563, 566-68 (2008).

${ }^{56}$ See id.

${ }^{57}$ See Dodge, supra note 1, at 258.

${ }^{58}$ See infra Part V.

${ }^{59}$ See, e.g., Deborah Schenk, A Positive Account of the Realization Rule, 53 TAX L. Rev. 354, 357 (2004) (characterizing the realization rule as disregarding "'mere' increases or decreases in value" between 
rule prevents taking account of fluctuations in an asset's value that arise during the taxpayer's holding period but does not require disregarding known future rights and obligations. The question of who is right, however, does not seem capable of a definitive answer if the standard view is correct. ${ }^{60}$ As developed below, under LAL it is clear that no inclusion arises for the borrower regardless of whether the realization rule is a feature of the tax.

\section{Treatment of Lender}

The treatment of the lender is somewhat less controversial. If the loan is not includible to the borrower, it should not generate a deduction to the lender, for at least two reasons. First, providing a deduction when there is no inclusion would cause the loan proceeds to drop out of the tax base while the loan was extended. Second, from the lender's perspective, the transaction can be seen as a straightforward purchase of an asset: the borrower's note. This note has a fair market value equal to that of the loan proceeds (assuming it provides for adequate interest) so that the lender has not lost anything in the exchange.

Similarly, if one considers that a better rule would treat the borrower as having income on receipt of the loan proceeds, it appears that the lender should have a deduction. ${ }^{61}$ Generally speaking, the theory would be that the loan represents a transfer of wealth from the lender to the borrower; it does not itself create value out of thin air. Correlatively, repayment is income to the lender if and only if the lender has deducted (and therefore the borrower has included) the loan proceeds on extension of the loan.

\section{Proposition 2: Both Parties Receive Basis Credit}

Whether and to what extent the parties to the loan have basis in what they receive is technically a further question. On the borrower side, a number of authorities and commentaries consider basis credit as self-evident under the assumption that the borrower has not received any net value, ${ }^{62}$ others, however, accept nontaxation (in whole or part) on

acquisition and disposition of a position); David M. Schizer, Realization As Subsidy, 73 N.Y.U. L. REV. 1549, 1555 (1998) ("When stock appreciates from $\$ 100$ to $\$ 400$, a taxpayer is $\$ 300$ wealthier; she is not taxed, though, until she disposes of the property."); White, supra note 1, at 2046 (discussing realization as described by the Supreme Court as involving separation or disposition, without reference to the period in which the disposition occurs). A legally binding repayment obligation does not qualify as a value fluctuation, or "market swing." In the loan setting, the realization rule as understood by Schenk (and others) merely prevents the parties from taking account of the effect of interest rate fluctuations on the value of the repayment obligation while the loan is outstanding. For example, if the loan is extended at five percent and interest rates rise, the present value of the repayment obligation drops, resulting in a benefit to the borrower and a detriment to the lender compared with what could be achieved under a newly negotiated loan. Under the realization rule, neither the borrower's relief nor the lender's loss is taken into account unless the loan is settled (or disposed of) during the period.

${ }^{60}$ Although not decisive, it is worth noting that the length of the taxable period is obviously a matter of convention that, in Dodge's view, has particularly significant consequences. If the period is one year, loan proceeds scheduled for repayment in two years would be taxable, but if it's ten years, they would not.

${ }^{61}$ Dodge is an exception. In his view, what requires inclusion for the borrower is the realization rule, which in his view precludes recognition of the obligation to repay until the period in which the repayment occurs. On the lender side, the realization of the benefit of extending the loan-namely, receipt of the borrower's note-occurs when the loan is made so that the borrower should continue to be treated as under current law: no deduction on extension and no inclusion on repayment. See Dodge, supra note 1, at 258-59.

${ }^{62}$ E.g., Comm'r v. Tufts, 461 U.S. 300, 307-08 (1983) ("Because of the obligation to repay, the taxpayer is entitled to include the amount of the loan in computing his basis in the property; the loan, under $\S$ 1012, is part of the taxpayer's cost of the property."); McMahon \& Simmons, supra note 1, at 418 ("If borrowed money is used to acquire property, the taxpayer's basis in the property under section 1012 is the full purchase price, including the borrowed funds applied to the purchase price. The repayment of the borrowed funds is a 
receipt of loan proceeds on the basis of policy reasons (rather than whether the proceeds are income in a pure sense) but remain unconvinced that full basis credit to the proceeds should also attach. They believe that if the receipt of loan proceeds is not taxable, the basis in the proceeds should be zero or, perhaps, at least not equal to their face amount, because the nontaxation of the received loan proceeds represents an override to income tax principles under which basis credit requires a taxable outlay.

The general rule for basis provides that it is equal to "cost." 63 Cost, in turn, is understood to reflect the amount of after-tax investment that the purchaser makes in the property. ${ }^{64}$ In an ordinary taxable transaction, after-tax investment will usually be fair market value regardless of whether the purchaser finances the acquisition with cash or property. ${ }^{65}$ Suppose Purchaser pays $\$ 1,000$ cash for Asset, which is worth $\$ 1,000$ (if Asset is worth a different amount, the parties are not dealing at arm's length or there is some other feature of the transaction besides a property sale). Except in unusual cases, ${ }^{66}$ the cash will have been taxed already so that Purchaser's basis in Asset is the purchase price or its $\$ 1,000$ cost (in those few cases in which the cash has not been taxed, basis in the purchased assets is generally disallowed). ${ }^{67}$ Similarly, if Purchaser instead exchanges appreciated property for Asset in a taxable transaction, Purchaser will recognize gain realized on the exchange and consequently have the same basis as in a cash purchase. Suppose Purchaser acquires Asset with X Co. stock, worth $\$ 1,000$ and in which Purchaser's basis is $\$ 700$. Purchaser recognizes $\$ 300$ of gain on the exchange ${ }^{68}$ and again takes a $\$ 1,000$ basis in Asset under section 1012, reflecting the $\$ 700$ of already-taxed investment in X Co. stock and the $\$ 300$ of gain that is taxed on the exchange.

By contrast, in those settings in which a purchaser's realized gain or loss is not recognized, basis ordinarily will not be cost but typically the basis that the purchaser had in the property used to acquire the asset in question. ${ }^{69}$ The basis rules for such nonrecognition transactions reflect the idea that because unrecognized gain or loss realized in the exchange is, for policy reasons, deferred rather than excluded, the pre-transaction basis must carry over after the transaction to ensure gain or loss recognition in the future.

prerequisite to full enjoyment of ownership and therefore represents a cost of the property.") (citing Tufts, 461 U.S. at 307-08) (footnote omitted).

${ }^{63}$ I.R.C. $\S 1012$.

${ }^{64}$ See BITTKER \& LOKKEN, supra note 3, at 942.1.

${ }^{65} \mathrm{See}$ I.R.C. $\S 61(\mathrm{a})(3)$.

${ }^{66}$ Two cases include a corporation's basis in certain assets purchased with nontaxable contributions to capital, see I.R.C. $\S 362$ (c)(2), and, subject to an election, the acquisition of property that replaces similar or related property destroyed in a casualty, see. I.R.C. § 1033(a)(2).

${ }^{67}$ See, e.g., I.R.C. $\$ 362(\mathrm{c})(2)$ (contributions of money to the capital of a corporation by nonshareholders do not generate basis in property purchased by the corporation with the contribution); I.R.C $\S 1033(\mathrm{~b})(2)$ (basis in property purchased that is similar to and replaces involuntarily converted property is reduced by nontaxed portion of recovery on the conversion).

${ }^{68}$ See I.R.C. $\$ 1001(\mathrm{a})$.

${ }^{69}$ See, e.g., I.R.C. $\$ 358$ (a) (transferor's basis in property received from corporation in a section 351(a) or section 354 exchange); I.R.C $\$ 722$ (transferor's basis in partnership interest received in exchange for property contributed to the partnership). As an alternative, it also can be the basis of the transferor, but this rule generally applies where the transferee is the successor to the transferor and is in some sense the transferor's proxy, such as the corporation or partnership that receives the property. See, e.g., I.R.C. § 362(a) (transferee corporation's basis in property received in a section 351(a) exchange is transferor's); I.R.C $\S 723$ (transferee partnership's basis in property received in a section 721 exchange is generally transferor's). Because the lender and borrower do not stand in this type of relationship, the only deferred-tax basis candidate for the borrower would be the exchanged basis rule described in the text. 
Suppose that Transferor's exchange of Blackacre for Whiteacre qualifies for nonrecognition as a "like-kind" exchange under section 1031. Transferor's basis in Whiteacre will be her basis in Blackacre, not the cost of Whiteacre. ${ }^{70}$ If she later disposes of Whiteacre in a taxable transaction, the built-in gain or loss in Blackacre that went unrecognized in the nontaxable exchange will be recognized at that time.

Suppose one accepts that the receipt of the loan proceeds is not taxable on the basis of some policy reason besides the goal of taxing true economic income. Because of its likeness to other nonrecognition transactions, the rule of nontaxation may give rise to the intuition that the borrower's basis in the loan proceeds should be either zero or at least not the face amount of the debt. ${ }^{71}$ Borrower has no after-tax cost in her promises to pay interest or to return the loan amount. If we are not going to tax her on the receipt, so the argument runs, we should also not give her basis credit since what justifies that credit is the presence of an after-tax investment, which is precisely what is missing under the nontaxation rule. Moreover, the fact that she is expected to repay the loan with taxed dollars does not justify basis credit on receipt of the loan proceeds. In the ordinary course, basis arises when payment is made (or liability accrues in the case of an accrual method taxpayer) because that is when tax is due. Basis credit would arise on the occasion of a taxable receipt of the funds used to repay the loan.

These considerations at least suggest that if one believes that the offsetting obligation theory justifies nontaxation of the loan exchange, one still might conclude that Borrower's zero basis in the promises should carry over to the cash received in exchange for them as it would in a typical nonrecognition transaction. ${ }^{72}$ That conclusion, in turn, could support either of two rules that are inconsistent with the actual rule. One rule would require Borrower to recognize gain on use of the loan proceeds to acquire property or services, effectively rendering the borrowing transaction taxable. The other possibility would be to require Borrower to take a zero basis in assets or services purchased with the loan proceeds, thereby denying cost recovery to Borrower and, in effect, taxing the loan proceeds over the useful life of the asset or service purchased with them (at least in the business and investment settings). ${ }^{73}$

For these reasons, some commentators have argued for at least limited basis credit in loan proceeds in certain circumstances even if the tax regime otherwise would not support it. ${ }^{74}$ Charlene Luke argues, for example, that providing full basis credit for loan

${ }^{70}$ See I.R.C. $\S 1031(\mathrm{~d})$.

${ }^{71}$ See, e.g., Charlene Luke, Of More than Usual Interest: The Taxing Problem of Debt Principal, 39 SeAttLe U. L. ReV. 33, 49-53 (2015) (arguing that borrowing of loan proceeds is conceptually distinct from "basis borrowing"); Polito, supra note 42, at 506-09 (arguing that any of a number of conventions could apply to treat loan proceeds as having basis to some extent); White, supra note 1, at 2072-73 (arguing that supplying basis credit is inconsistent with nontaxation of the receipt of loan proceeds).

72 See, e.g., I.R.C. $\$ 358$ (a) (exchanged basis in nontaxable reorganization and incorporation transactions); I.R.C. $\$ 723$ (same in partner-partnership transactions); I.R.C. §1031(d) (same in like-kind exchange transactions).

${ }^{73}$ As a general matter, there is no cost recovery for the ordinary use of personal-use property so that taking a zero basis in such property would not be significant except upon later disposition of the asset in a taxable transaction. See I.R.C. $\S 165$ (permitting a deduction for losses sustained on business assets, assets used in the production of income, and certain casualty losses); I.R.C. $\S 167$ (permitting cost recovery for assets used in a trade or business or for the production of income).

${ }^{74}$ See, e.g., William D. Andrews, A Consumption-Type or Cash Flow Personal Income Tax, 87 HaRV. L. ReV. 1113, 1154-55 (1974); J. Clifton Fleming, Jr., The Deceptively Disparate Treatment of Business and Investment Interest Expense Under a Cash-Flow Consumption Tax and a Schanz-Haig-Simons Income Tax, 3 Fla. Tax REV. 544, 561 (1997). 
proceeds may be more appropriate when there is assurance that the tax benefits that the borrowing finances are not inconsistent with income tax principles, ${ }^{75}$ in situations in which borrowing furnishes a tax timing or other tax advantage, basis rationing may be appropriate. ${ }^{76}$ Polito argues that basis credit may be more appropriate when the borrowing transaction involves an actual cash transfer than when it does not. ${ }^{77}$ Shaviro has suggested that denying basis credit for nonrecourse debt may be appropriate because of the contingency of the repayment obligation or because the justifications for not taxing unrealized gains are particularly weak when the borrower uses appreciated property as a security. ${ }^{78}$

\section{Proposition 3: Borrower Default Triggers an Inclusion}

Discharge of indebtedness gives rise to gross income, ${ }^{79}$ though discharged indebtedness may be excluded in some circumstances. ${ }^{80}$ There is wide agreement that the discharge of debt ought to be taxable (as long as no exclusion applies) assuming that receipt of the loan proceeds is not, although it took some time to settle on the rationale. ${ }^{81}$ In the early years of the income tax, authorities tended to focus on the question of whether the debt discharge "freed up" assets of the borrower, thereby resulting in an increase in net worth. ${ }^{82}$ Thus, when the debt was discharged by reason of insolvency, the courts would find no income from DOI on the basis that the discharge did not improve the borrower's balance sheet. Another rationale that was sometimes offered was that the question of income from DOI hinged on the overall success of the borrowing-plus-finance transaction: if the overall arrangement was a bust, courts might find that the discharge did not create income to the borrower even if the borrower was solvent. ${ }^{83}$

In the last several decades, a consensus has coalesced around a different theory for inclusion of income from DOI, sometimes termed the "tax benefit" theory, in analogy to the tax benefit rule (TBR). ${ }^{84}$ The TBR requires the taxpayer to include an item of gross income in the current period if an event occurs in that period that is "fundamentally

${ }^{75}$ Luke, supra note 72 , at $40-50$.

${ }^{76} \mathrm{Id}$. at 66-77.

${ }^{77}$ Polito, supra note 42, at 626-32. I find Polito's distinctions unconvincing. If the borrower receives value from the lender, the absence of an intervening cash transaction seems beside the point. In support of his argument, Polito cites to cases involving promissory notes in which the putative borrower received no value for the note. See id. at 629 n.45. In those cases, there was a substantial question of whether the debt was genuine.

${ }^{78}$ Shaviro, supra note 1, at 407.

${ }^{79}$ See I.R.C. § 61(a)(12).

${ }^{80} \mathrm{See}$ I.R.C. $\$ 108$.

${ }^{81}$ See BitTKer \& LOKKEN, supra note 3, at 9 7.1. For a history of the tax treatment of DOI income, see McMahon \& Simmons, supra note 1, at 417-25.

${ }^{82}$ See U.S v. Kirby Lumber, Co., 284 U.S. 1, 3 (1931).

${ }^{83}$ See, e.g., Bowers v. Kerbaugh-Empire Co., 271 U.S. 170 (1926) (no DOI income when overall transaction of which borrowing was a part generated a loss to the taxpayer).

${ }^{84}$ The leading cases are Crane v. Commissioner, 331 U.S. 1 (1940), and Commissioner v. Tufts, 461 U.S. 300, 309-10 (1983) ("[The tax benefit] treatment balances the fact that the mortgagor originally received the proceeds of the nonrecourse loan tax-free on the same assumption. Unless the outstanding amount of the mortgage is deemed to be realized, the mortgagor effectively will have received untaxed income at the time the loan was extended and will have received an unwarranted increase in the basis of his property."). See also Vukasovich, Inc. v. Comm'r, 790 F.2d 1409, 1415 (9th Cir. 1986) ("We have no doubt that an increase in wealth from the cancellation of indebtedness is taxable where the taxpayer received something of value in exchange for the indebtedness."); Boris I. Bittker \& Barton H. Thompson, Jr., Income from the Discharge of Indebtedness: The Progeny of United States v. Kirby Lumber Co., 66 CAL. L. REV. 1159 (1978). 
inconsistent" with the basis upon which the taxpayer claimed a tax benefit in an earlier period. ${ }^{85}$ For example, a taxpayer might deduct the cost of business supplies in Year 1, only to go out of business unexpectedly in Year 2 before the supplies were exhausted. The TBR would generally require inclusion of the cost of the unused supplies in Year 2, ${ }^{86}$ subject to a limited statutory exception. ${ }^{87}$

The TBR analogy to the loan proceeds case runs as follows. ${ }^{88}$ Non-inclusion of loan proceeds when the loan is extended constitutes a tax benefit to the borrower that rests on the assumption that the borrower will repay the loan. If on the loan date that obligation had not existed, so the argument runs, then receipt of the loan proceeds would have been taxable as a simple accession to wealth. In the DOI case, the repayment assumption is in fact false, but that is not known until a later period, when the borrower defaults. Since the only difference (again, as the argument runs) between a taxable transfer in the year the putative loan is made and the actual DOI case is that the obligation is canceled in a later period, inclusion of loan proceeds in that period is said to be necessary as a means to correct the earlier mistake - that is, to reverse the untoward tax benefit. ${ }^{89}$ Put otherwise, the fact that the assumption of repayment turns out to be incorrect after the loan is extended rather than contemporaneously with it seems to be an arbitrary basis to treat the two cases differently. In both, the taxpayer accedes to wealth. "[T]ransactional parity" therefore demands an inclusion in the discharge year. ${ }^{90}$

The loan discharge case bears obvious similarities to the TBR. As in the usual TBR case, an event happens in an earlier year (the borrowing transaction) that appears to provide a tax benefit (non-inclusion of loan proceeds), and that benefit is predicated on a genuine but ultimately mistaken assumption about what the taxpayer will do at a future date (repayment) at the time the benefit is claimed. In further analogy to the TBR, in the later period, when the assumption turns out to be incorrect, the taxpayer turns out to have obtained a benefit in the earlier period to which she was not entitled. Consequently, a corrective inclusion is appropriate.

One virtue of the TBR rationale is that it does not tie the treatment of the debt discharge to the fate of the loan proceeds. ${ }^{91}$ As one prominent commentary has noted:

${ }^{85}$ Hillsboro Nat'l Bank v. Comm'r, 460 U.S. 370, 372 (1983).

${ }^{86}$ See id. at 381-82.

${ }^{87}$ Section 111(a) permits the taxpayer to avoid an inclusion under the TBR to the extent that the prior year's benefit provided no actual tax benefit.

${ }^{88}$ See, e.g., BITTKER \& LOKKEN, supra note 3, at 7.1 (discussing the TBR analogy).

${ }^{89}$ See Hillsboro, 460 U.S. at 383 ("The basic purpose of the tax benefit rule is to achieve rough transactional parity in tax, see n 12, supra, and to protect the Government and the taxpayer from the adverse effects of reporting a transaction on the basis of assumptions that an event in a subsequent year proves to have been erroneous."). See also McMahon \& Simmons, supra note 1, at 426 (“[W] hen the debt is discharged, in whole or in part, without payment, inclusion in gross income of cancellation of debt income is required to offset the original favorable tax treatment.").

${ }^{90}$ Hillsboro, 460 U.S. at 383.

${ }^{91}$ See, e.g., BitTKer \& LOKKEn, supra note 3, at 7.6 ("Income from discharge of indebtedness should depend not on the type of debt, but only on the spread between the amount received by the debtor and the amount paid to satisfy the obligation."); Geier, supra note 1, at 145 ("Exclusion from gross income on receipt of the loan proceeds ... is premised on the obligation to repay with after-tax dollars. When that obligation disappears, so does the justification for the initial exclusion."); and 163 ("[T]he justification for taxing both COD income and the gain arising under the collapsed approach [i.e., satisfaction of nonrecourse debt by delivering security to the lender] is the same: the release from the obligation to repay previously received untaxed loan proceeds with after-tax dollars.") (emphasis omitted). 
Since borrowed funds are obviously worth their face amount and assets acquired on credit in an arm's length transaction are also worth what the buyer agrees to pay, a debtor who ultimately pays back less than was received enjoys a financial benefit whether the funds were invested successfully, lost in a business venture, spent for food and clothing, or given to charity. ${ }^{92}$

This analysis seems to be correct given the additional welfare that the discharged borrower enjoys when compared to a non-borrower, regardless of the success or failure of the loan-financed transaction or of the solvency of the borrower. Consider, for example, two individuals, $A$ and $B$, who each have 0 wealth. $A$ does nothing, while $B$ borrows $\$ 100$ from Lender to bet on a sporting event, loses the bet, and defaults on the loan. $B$ has done better than $A$ because $B$ enjoyed the gambling opportunity that the borrowing made possible. Parity requires an inclusion for $B$ regardless of the fact that the debt-financed transaction was unsuccessful. Although it may make sense to provide an exclusion or other tax relief to a borrower that defaults because of insolvency (or for other reasons), the fact of insolvency does not eliminate the economic benefit that the loan provided to the borrower.

Nevertheless, and despite the virtues of applying the TBR analogy to loan proceeds, the reasons for doing so are obscure. Ultimately, the argument assumes its conclusion. The main difficulty arises in trying to make sense of the counterfactual that would have denied the tax benefit $a b$ initio. In the basic TBR scenario, what turns out to be incorrect is not the assumption that the earlier transaction occurred but that the set of circumstances that would justify the claimed tax benefit obtained. ${ }^{93}$ In the business supplies case, what turned out to be incorrect was the assumption that the taxpayer would use the purchased supplies in her business, not that she purchased them at all. The "fundamentally inconsistent" later development was what turned out to be the case with respect to justifying the tax benefit, namely that she went out of business. Consistent with this approach, operation of the TBR does not amount to applying the tax law to what would have happened as a factual matter had the tax benefit been unavailable, but instead applying the tax law to what did occur in light of developments that made claiming the tax benefit erroneous.

The difficulty of extending this analysis to the loan case is that it is not even possible that the loan transaction would have occurred had all facts been known when the loan was made. Rather, the analogy supposes that what appeared to be a loan was not a loan. Consider the odd nature of the DOI formulation, as described by the same commentary:

Were we blessed with perfect foresight, it would be possible to exclude borrowed funds from gross income only to the extent of the ultimate repayment and to tax at the outset the amount that will not be repaid. However, in the absence of perfect provision, a second best solution is required. One alternative would be to tax the entire amount borrowed and to allow deductions only when, as, and if the debt is repaid. Since most

92 BITTKER \& LOKKEN, supra note 3 , at 97.1 .

${ }^{93}$ See Hillsboro, 460 U.S.at 383 ("The basic purpose of the tax benefit rule is to achieve rough transactional parity in tax ... and to protect the Government and the taxpayer from the adverse effects of reporting a transaction on the basis of assumptions that an event in a subsequent year proves to have been erroneous."). 
loans are paid in full and taxing the receipt would impose a heavy frontend burden on debt financing, a better alternative is the existing system of excluding borrowed funds from gross income and requiring the taxpayer to account for any gain if the debt is later settled for less than the amount due. $^{94}$

The main difficulty can be simply stated: In the DOI case, the counterfactual does not assume that the event, namely, the loan, occurred but its tax attributes differed; rather it assumes that the event did not occur at all. Instead, a different event occurred: the uncompensated transfer of value to the borrower in the year the loan was extended. By contrast, in the TBR case, the event occurred, but the circumstances thought to obtain that would justify a tax benefit did not in fact obtain. Indeed, the fact that the original transaction could have happened without the tax benefit is a predicate to applying the TBR, since that is exactly what it does: apply the correct tax law to what actually happened. In the supplies case, no one asserts that the taxpayer did not purchase the supplies, but in the loan case, to characterize the forgiveness as akin to an uncompensated transfer when the loan originated is simply question-begging. Of course such a transfer would generate income, but such a transfer is not a loan. To treat the cancellation of the loan as such a transfer is simply to conclude that the forgiveness should be income to the borrower, not to argue for it.

There is a further related difficulty with application of the TBR to loans: how to account for the interest that was paid on amounts discharged in a later year. Had the parties known from the start that the borrower would not repay the loan, the borrower would not have paid interest on that amount thereafter. If one wanted to apply the TBR analogy consistently, one would have to account for the erroneous payment of interest on amounts that were not "in fact" borrowed. It is hardly a point of transactional consistency to require an inclusion in the later period of the discharged amount but not to account for the interest that had been paid to that point. One might object that interest payment was appropriate given that the loan was outstanding before default, but this observation simply highlights that the TBR analogy is misplaced, not that the interest should be retroactively canceled if the TBR analogy is to be applied consistently to all aspects of the transaction. Under the TBR analogy, the loan did not occur to the extent of the discharge, and therefore interest should not have accrued.

III. LOAN AS LEASE

If nothing else, the criticisms reviewed above of the existing tax treatment of loans indicate that the treatment rests on shaky conceptual ground. Even if one agrees with the current regime (in whole or part), the regime seems hard to defend in its entirety given the standard view of the nature of the loan transaction.

This Part develops the point that there are substantial reasons to treat the criticisms as evidence of the failure of the standard view rather than as cogent challenges to (most of) the existing tax rules. The basic difficulty with the standard view is that it mistakes the physical events that occur in the loan transaction for the legal relations that the loan creates between the parties. ${ }^{95}$ A focus on the legal relations demonstrates that a loan is closely

\footnotetext{
${ }^{94}$ BITTKER \& LOKKEN, supra, note3, at 97.1 (footnote omitted).

${ }^{95}$ In this respect, the criticism developed here represents an instance of what Hohfeld characterized as a general problem of jurisprudence. See Hohfeld, supra note 17, at 22-25. See also Pierre Schlag, How to Do Things with Hohfeld, 78 L. \& ConTeMP. РROB. 185, 193 (2015) ("The second kind of mistake [that Hohfeld
} 
akin to an ordinary lease arrangement. As indicated earlier, LAL does not result in tax rules that differ materially from those just described. It does, however, have two important virtues. First, it places the existing rules on firmer foundations, eliminating significant confusion about the conceptual basis for the current regime and, one hopes, tamping down calls for reform that purport to rest on the nature of an income tax. Second, LAL has important ramifications for the existing rules in the partnership tax area because of the mechanism that the partnership tax regulations adopt to allocate basis credit among the partners when the partnership borrows. ${ }^{96}$ As contrasted with the three propositions that have been the focus to this point, LAL would counsel significant changes to the partnership tax rules.

The discussion in this Part proceeds as follows. Subpart A develops the analysis of LAL. Subpart B analyzes the tax consequences of a simple loan in which the loan creates no risk of loss to the lender. The objective is to characterize the legal relations that arise purely from a purchase of liquidity. Risk of loss is present, however, in most loan arrangements, and its presence signifies that the borrower purchases more than liquidity in the loan. When risk is present, the arrangement includes a risk-shifting provision that requires separate analysis. That analysis, however, does not change the basic conclusion that ongoing payments from the borrower to the lender reflect the full cost of what is purchased under the loan. The addition of risk-shifting is the subject of Subpart C. Finally, Subpart D addresses the question of whether the tax treatment of loan proceeds ought to depend on whether the interest is deductible.

A. What is a Loan?

The standard view characterizes a loan as a swap of cash for promises to pay interest and to return the cash by the end of the term. LAL views the consideration in a loan transaction by analogy to the rent that a lessee pays to the lessor, the analog of which is interest paid for use. If the consideration for the loan is simply the obligation to pay interest, essentially all of the tax problems asserted to exist under the standard view disappear.

Begin with a basic lease. In a simple lease arrangement, the lessee enjoys use of the underlying property for a specified term in exchange for periodic rental payments. ${ }^{97}$ The parties do not contemplate their bargain to consist of a transfer of the fee interest in exchange for the promise to return it together with rent, and the law does not so treat it. (If it did, nonpayment of rent would not necessarily be a basis to terminate the lease ${ }^{98}$ ). Rather, the leasehold is its own interest in the land that the lessee purchases; the transfer and retransfer of (mere) possession, which physically resemble transfers of a fee interest,

identified] ... lies in confusing and conflating legal 'concepts' with the nonlegal 'objects' to which they ostensibly apply.").

${ }^{96}$ See in particular Treas. Reg. $\S \S 1.752-1,-2 \&-3$.

${ }^{97}$ For typical definitions, see, e.g., U.C.C. § 2A-103(1)(j) (AM. L. INST. \& UNIF. L. CoMM’N 1977) ("'Lease' means a transfer of the right to possession and use of goods for a term in return for consideration ...”); 15 WEST's TEXAS FORMS $\S 16.1$ (“A 'lease' is a contract by which a property owner grants the right to possess property for specified period of time in exchange for a periodic payment of a stipulated price, or 'rent."') (citation omitted). The Restatement of Property defines a lease to involve a transfer of possession, as contrasted with a transfer of ownership. See Restatement (SECOnd) Of Prop., LandLORD \& TENANT, § 1.2 (AM. L. Inst. 1977). The Restatement also characterizes as "the most crucial point" of the parties' covenants "the landlord's right to terminate the lease and regain possession for non-payment of rent." Id. at Part I.

98 See, e.g., Restatement (SECOND) OF Prop. § 13.1 (AM. L. InSt. 1977) (Tenant's nonperformance of promises under the lease entitles landlord to terminate lease). 
are incidental to the purchase of the leasehold. If it were possible (and perhaps it someday will be possible) to effectuate the transfer of a time-slice such as a leasehold by literally separating the parts of the assets temporally, there would be no physical transfer of the remainder interest in the subject property - at least in the case of a riskless lease. Rather the leasehold would simply disappear at the end of the rental term (or earlier on default) and the fee would reappear to the holder of the remainder. Indeed, a similar type of arrangement is already common in certain licensing transactions involving computer software. ${ }^{99}$ The owner of the software licenses the right to use the software for a period and also controls the software itself such that the licensee is literally unable to use the software on expiration of the license.

One might consider the difference between LAL and the standard view to be a matter of arbitrary choice, much as the Ptolemaic and Copernican theories of the solar system are in some sense merely alternative descriptions of the same basic reality. ${ }^{100}$ In that case, viewing a loan as a rental of money would not be superior to the standard view, except perhaps in its having the aesthetically pleasing property of greater simplicity. The differences, however, run deeper than aesthetics. Remaining for the moment with a riskless loan, the rationale for treating the lessee as purchasing a time-limited interest in the property and not as receiving the fee subject to a return obligation is that the lessee by definition acquires literally no rights in or power over the remainder. That is equivalent to saying that the remainder is not transferred as part of the bargain, a real difference from a transaction in which rights are transferred, including the loan transaction as conceived in the standard view. The fact that rights in the remainder are not transferred implies in turn that the factual transfer of the remainder is incidental to the parties' deal, as described above. Because there is no exchange of the remainder or any part of it for consideration, the deal between the parties consists of the payment of rent for use during the term. No return obligation arises because there is nothing to "return."

Additional economic facts of the standard rental arrangement corroborate the point. Nonpayment of rent ordinarily results in default and a transfer back of possession, not in an action for damages lying with the lessor coupled with an ongoing right of the lessee to occupy the property throughout the lease term. If the deal were understood to include a transfer of the fee interest in exchange for the obligation to return it, nonpayment of rent would not necessarily result in termination of the leasehold. Consider, for example, a one-year lease of Blackacre, with rent payable monthly. The rental value of Blackacre represents a small proportion of the value of Blackacre, such that nonpayment of rent in most circumstances would not constitute a material breach of the parties' agreement.

${ }^{99}$ For a typical example, see Michael Wozniak, Two Ways to Control Subscription Software Licenses, SOFTWARE KEY SYS., https://www.softwarekey.com/blog/licensing-tips/two-ways-controlsubscription-software-licenses/ [https://perma.cc/NUS4-NK7U]. A difference is that the license is rarely exclusive in this case, so that the licensor retains a right to use the property. In the case of an exclusive license, the licensor's non-use of the licensed property during the term would take the form of a contractual promise and not a physical deprivation of the capacity to use it.

100 This appears to be the perspective adopted by Reed Shuldiner in one of only two other commentaries I have been able to locate that analogize loans to rent. Reed Shuldiner, Indexing the Tax Code, 48 TAX L. REV. 537, 592 (1993) (describing discrepancies between the tax treatment of rental arrangements and loans as due to "fundamental accounting differences"). The other commentary advocates for a position opposed to the one here that rental arrangements should be treated as loans. George Mundstock, Taxation of Business Rent, 11 VA. TAX REV. 683, 700-03 (1992).

On the relationship of Ptolemy to Copernicus, see for example ThOMAS S. KuHN, THE CopernicAN REVOLUTION 186 (1957) (noting that at one level Copernicus's work could be taken as simply a more tractable description of the Ptolemaic geocentric view). 
Rather, the bulk of the lessee's obligation would consist in the obligation to return the fee at the term and therefore nonpayment of rent would merely entitle the lessor to damages but not to repossession. In fact, rental arrangements commonly provide for cancellation of the lease on uncured nonpayment of rent. ${ }^{101}$

A similar set of rules commonly operates in loan arrangements. The borrower agrees to pay interest, and nonpayment typically entitles the lender to accelerate the loan if the borrower does not timely cure. ${ }^{102}$ Even where there is a possibility of curing a default, the norm is that the borrower will accrue additional interest that must be paid by reason of commandeering extra liquidity. ${ }^{103}$ In all events, loan arrangements do not permit indefinite nonpayment of interest; even those loans that simply penalize a default on initial nonpayment of interest or principal will accelerate the loan if the borrower does not cure the default in a reasonable time, typically well short of the actual term of the loan. ${ }^{104}$

B. What Tax Consequences Follow From LAL?

Application of LAL clarifies why the basic tax rules for debt are mostly correct. It also indicates why other rules need revision. The balance of this Part addresses the first of these topics, focusing again on Propositions 1, 2 and 3 but from the LAL perspective. This Subpart considers a riskless loan, while Subpart C extends the analysis to include the riskshifting that occurs in most loans. Because a riskless loan by definition cannot go into default, the discussion of DOI income is deferred to Subpart C.

Considered economically, in a loan the borrower purchases a time-slice of the subject property - the cash borrowed - in exchange for interest payments. In the typical loan, payment of interest is an ongoing obligation. Failure to pay interest accelerates the loan or, if it does not accelerate it, generates an obligation to pay interest on the interest such that the same overall result obtains as long as the interest is actually paid; ${ }^{105}$ moreover, once it becomes clear that interest will not be paid, the loan becomes immediately due. These facts indicate that in economic substance, each interest payment purchases use for a given period. This is a simple value-for-value exchange. Consequently, setting aside for the moment the possible effect of deductibility on the payment of interest, the borrower has full basis in the use of the proceeds (not in the remainder) for the period for which interest is paid for the simple reason that the interest payment represents a purchase at the cost of the time-slice with after-tax dollars. Hence there is no question of inclusion on

101 See, e.g., Revised Unif. LANDlord And Tenant ACt § 601(a)(1) (UNIF. L. Comm’n 1972) (providing that a landlord may terminate a lease for nonpayment of rent due by giving the tenant notice in a record stating that if the rent remains unpaid 14 days after the notice is given the lease terminates).

${ }^{102}$ See, e.g., Ross P. Buckley, Why Are Developing Nations So Slow to Play the Default Card in Renegotiating Their Sovereign Indebtedness, 6 CHI. J. INT'L L. 345, 346 n.3 (“Under most loan agreements and bonds, nonpayment of interest or principal is a ground upon which a creditor can declare a debtor in default, but default is not an automatic event.").

103 See, e.g., Prompt Payment, Bureau of THE Fiscal Serv., https://www.fiscal.treasury.gov /prompt-payment/interest.html [https://perma.cc/8TB3-63RG] (last visited Mar. 21, 2021) (explaining that interest accrues on a late loan payment by applying the interest rate to the late amount under usual compounding principles).

104 Loan Agreement: Overview, PRAC. L. FIN., https://www.westlaw.com/8-3810296? transitionType $=$ Default\&contextData $=($ sc.Default $) \& V R=3.0 \& R S=$ cblt1.0 (last visited Feb. 16, 2021), ("[Defaults] are events (such as non-payment of interest or principal ...) which allow lenders to exercise their remedies. These remedies allow the lenders to accelerate the repayment of outstanding debt ...").

${ }^{105}$ Original issue discount bonds are debt instruments on which interest due is simply added to the outstanding principal amount rather than paid to the bondholder so that more interest accrues as time passes. See I.R.C. $\S \S 1271-73$ (so treating bonds for tax purposes whose stated redemption price at maturity exceeds their issue price by more than a de minimis amount). 
receipt of the time-slice because there is nothing to include, apart, possibly, from the value of the first interest period. But just as a lessee does not include the value of a leasehold or even of the first rental period on taking possession, it seems administratively much simpler to disregard this relatively minor benefit. ${ }^{106}$

On the lender side, the sale of the use is an exchange that generates gain only as use arises, which gain is simply interest. Because the transfer of the loan proceeds is itself incidental, there is no deduction on transfer because from a legal perspective the loan proceeds have not changed hands.

One might imagine more nuanced fact patterns, but the basic analysis remains. Consider, for example, early repayments. In many self-amortizing loans, early payments apply against principal so that interest that accrues going forward is reduced. ${ }^{107}$ But the parties may agree that prepayments can be considered simply as they are labeled. In that case, a designated prepayment of interest results in the borrower's having paid for use in upcoming periods and, consequently, having no income during those periods either. Conversely, for a cash-method taxpayer, delayed payment of interest could, based on the general rules for inclusion of income, generate income to the borrower if payment occurs after the close of the taxable year. ${ }^{108}$ Consistent with the idea that the income received is the rental value of the money, the amount of the inclusion is simply the interest that goes unpaid until the later period.

Finally, LAL explains the difference between prepaid income items and loan proceeds. The issue in the prepaid income setting is whether an accrual-method service provider - the seller - should include a payment in income even though services are to be provided in a later tax period. ${ }^{109}$ LAL clarifies that in the loan setting it is the lender who is the service provider, not the borrower. The use of the loan proceeds is not analogous to a payment but to what is purchased; interest is the payment. The borrower is the service recipient. As a service provider, the lender does not have prepaid income under a standard lease because interest is paid as use occurs.

\section{LAL When the Lender Assumes Risk}

The analysis in Subpart B assumed that the lender bears no risk of borrower default. Ordinarily, only short-term Treasury bonds are considered riskless instruments, and even that assumption is somewhat stylized since it is theoretically possible for the U.S. government to default. ${ }^{110}$ In the more realistic case in which the lender assumes risk, the

106 To illustrate, suppose a loan is extended on the $15^{\text {th }}$ day of the month with interest payments due monthly on the $15^{\text {th }}$ of each subsequent month that principal is outstanding. Technically a calendar-year borrower has 16 days of income in respect of the liquidity purchased for the period from Dec. 16 through Dec. 31 , because payment therefore is not made until Jan. 15 of the next tax period. Just as the tax law disregards the analogous income in the case of a lease with a rent payment due on the $15^{\text {th }}$, it makes sense to disregard this timing benefit because it is de minimis.

${ }^{107}$ For a typical statement, see, e.g., How Does Prepaying Your Mortgage Actually Work?, SENSIBLE FIN. Plan. (Apr. 25, 2017), https://www.sensiblefinancial.com/prepaying-mortgage-works/ [https://perma.cc /QBP8-PWW2] ("When you make an extra payment on your mortgage, that money goes directly toward reducing the balance on your loan. Because of how the loan is structured, the extra payment triggers a cascade effect that speeds up the repayment of the loan.").

108 Treas. Reg. § 1.451-1(a). An accrual-method taxpayer generally would treat payment as accruing in the year of receipt of the loan proceeds under the all-events test. Treas. Reg. $\S 1.461-1(\mathrm{a})(2)$.

${ }^{109}$ I.R.C. $§ 451(b)$.

110 See, e.g., Joseph Bankman \& Thomas Griffith, Is the Debate Between an Income Tax and a Consumption Tax a Debate About Risk? Does It Matter?, 47 TAX L. ReV. 377, 387 n.29 (1992); Alvin C. 
analysis changes somewhat because the borrower's power to dissipate the lender's fund implies that something beyond mere liquidity is transferred in the transaction.

Risky loans grant the borrower a limited power to dissipate the fund because the loan is obtained for the purpose of spending the funds and there can be no guarantee that the borrower's assets will suffice to repay at the term. The extent of the grant differs, however, depending on the circumstances of the loan. Loans are commonly extended only for particular purposes, thereby providing some comfort that the loan is unlikely to be spent on risks unacceptable to the lender. The lender may reserve rights to monitor the borrower, such as to observe and even affect the borrower's decision making. A further circumstance that provides some protection to the lender is that under a recourse arrangement all of the borrower's assets are available to satisfy the debt (subject to claims of equal and superior creditors), and under many loan arrangements, the lender takes a security interest in the borrower's property. Of course, the most significant factor is the overall financial health of the borrower.

There are two ways in which these circumstances might be enlisted to support the idea that part of the bargain consists of a taxable exchange: viewing risk of loss as evidence of a fee transfer coupled with a promise to repay; and viewing the possibility that consideration provided to the lender in exchange for its assumption of risk might generate taxable gain or loss to the borrower. For reasons developed below, neither of these theories is correct.

\section{Considering the Risk of Loss as a Partial Receipt of the Fee}

It may appear that the borrower's power to dissipate the loan proceeds represents a transfer of more than mere use during the loan term, consistent with the idea that there is a transfer of at least part of the fee interest in the cash when the loan is extended and a transfer of it back if and when the borrower repays. If the borrower is capable of dissipating the loan, doesn't that mean that she received the proceeds in fee?

Two features of the arrangement explain why this conclusion is incorrect. The first is that the legal relation that the loan establishes with respect to the remainder falls far short of a right to the loan proceeds beyond the term and, therefore of an obligation to return them at the end of the term. Rather, the borrower might be considered, to use the language of Hohfeld, to have acquired a "privilege" vis-à-vis the lender during the loan term, who correspondingly has a Hohfeldian "no right."111 The privilege is the capacity to spend the funds (as well as other assets that the borrower owns) in ways that may make the borrower unable to repay at the term, matched by the lender's lack of a right to prevent the spending. Possession of the privilege, of course, does not discharge the borrower of the obligation to repay - the lender still has a right to be repaid — but it does have the capacity to alter the lender's legal claims with respect to the funds after the earlier of the term or when interest that is due goes unpaid. Generally speaking, if the borrower is unable to repay, the usual remedy is discharge in bankruptcy, which effectively defeats the lender's repayment right in whole or part. ${ }^{112}$ Remaining with the language of Hohfeld, a bankruptcy discharge

Warren, Jr., How Much Capital Income Taxed Under an Income Tax Is Exempt Under a Cash Flow Tax?, 52 TAX L. REV. 1, 14 (1996).

${ }^{111}$ For Hohfeld, A's privilege to $\mathrm{X}$ is A's capacity to do $\mathrm{X}$ without interference from $\mathrm{B}$, who correspondingly enjoys a "no right." Hohfeld, supra note 17, at 16.

112 See, e.g., Discharge in Bankruptcy - Bankruptcy Basics, U.S. CourTs, https:// www.uscourts.gov/services-forms/bankruptcy/bankruptcy-basics/discharge-bankruptcy-bankruptcy-basics [https://perma.cc/V8UT-W846] (last visited Mar. 21, 2021) (“A bankruptcy discharge releases the debtor from 
reflects the exercise of a power in the borrower, corresponding to a liability in the lender. Generally speaking, a party has a power when she can alter another party's legal entitlement with respect to some thing, and a party that is under a liability is powerless to control that alteration whether she approves or not. ${ }^{113}$ Although the borrower has no right to refrain from repayment, as a practical matter she can end up creating that right in herself by failing to maintain the ability to repay - whether or not through any fault of her own.

The just-described privilege and power that the borrower has in relation to the lender has a value, but that value generally is small. We know its value because we know that borrowers other than the federal government pay a risk premium to borrow, and the risk premium is simply the price of the privilege and the power that the borrower receives under the loan. Over the last 35 years, the risk premium for large borrowers has averaged about three percent in excess of the rate on 12-month Treasury obligations-considerably less than a right to the loan proceeds beyond the term. ${ }^{114}$ Of course, rates are higher for riskier debt, but even non-investment grade borrowing typically bears a rate not higher than about 15 percent before subtracting the risk-free rate. ${ }^{115}$ Thus, even if one wanted, under the standard view, to treat the promises made by the borrower to go beyond the obligation to pay for the time value of money, those promises reflect a small proportion of the face amount.

Secondly, and more to the point, because the borrower pays a risk premium on an ongoing basis in exchange for the privilege and the power, the essential character of the transaction as a fully paid-for taxable exchange remains unchanged. In each period, the borrower pays the pure cost of liquidity and a risk premium that reflects the parties' judgment of the fair market value of the privilege and power discussed above. Consequently, for the same reasons as previously noted, the borrower does not have income on receipt of the loan proceeds, the lender has no deduction from the transfer, and both parties have full basis in their respective legal entitlements. ${ }^{116}$ These entitlements simply include the privilege and the power described previously.

\section{Provision of Security and Covenants}

A separate basis on which to conclude that the extension of the loan may be taxable to the borrower relates to the consideration that the borrower provides the lender for the lender's willingness to assume risk of loss. Here one might accept LAL as the theory of the loan transaction but point to the fact that a cash risk premium is not the only form of consideration paid to the lender. For example, the borrower may provide collateral to the lender that consists of appreciated property or may agree to provide zero-basis services to

personal liability for certain specified types of debts. In other words, the debtor is no longer legally required to pay any debts that are discharged.”); U.S.C. $\$ 1328(a)-(c)$.

${ }^{113}$ Id. See also Curtis Nyquist, Teaching Wesley Hohfeld's Theory of Legal Relations, 52 J. LEG. ED. 238, 240 (2002) ("A person with a power is able to change a legal relation of another (who is under a liability).").

114 Historical Interest Rates: January 1986 to August 2020, FIRST REPUBLIC BANK, https://www.firstrepublic.com/finmkts/historical-interest-rates [https://perma.cc/DDU4-8M5F] (last visited Mar. 21, 2021).

${ }^{115}$ ICE BofA US High Yield Index Effective Yield, FeD. RSRV. BANK OF ST. LouIS (1997-2020) https://fred.stlouisfed.org/series/BAMLH0A0HYM2EY [https://perma.cc/7AC5-P52K] (last visited Mar. 21, 2021). The only time during this period that rates exceeded 15 percent was in the immediate aftermath of the 2008-09 Great Recession. Id.

${ }^{116}$ Some have suggested that the features of nonrecourse debt are enough like a sale to make the transaction taxable, since the borrower can lock in gain by pledging appreciated property. See supra text accompanying notes $49-51$. 
the lender (such as furnishing financials). ${ }^{117}$ In either case, if the transferred interest is substantial enough, the transaction might be considered taxable. Assume Borrower pledges Whiteacre as security for a $\$ 1$ million loan from Lender. Borrower's basis in Whiteacre is $\$ 700,000$ and its fair market value is $\$ 1.2$ million. By pledging Whiteacre, Borrower has transferred some of the incidents of ownership to Lender, such as limitations on use or perhaps reporting obligations with respect to the security or, more generally, with respect to Borrower's activities. Do these transfers count as taxable events?

With respect to collateral, it is clear that the transaction would not qualify as a taxable event under well-developed realization doctrine principles. In general, realization occurs when there is a "disposition" of property. ${ }^{118}$ A disposition for tax purposes requires substantially more than placing an encumbrance on property. For example, the sale of a call option for property held by the taxpayer does not qualify as a disposition of the property unless the option is so favorable that its exercise is all but assured. ${ }^{119}$ Nor do loans of property - that is, standard leases — qualify as realization events. ${ }^{120}$ If an option sale or a loan of property does not qualify as a disposition, then a transfer to the lender of rights significantly less extensive than these does not either.

With respect to zero-basis services, the question is closer, though of less practical importance. The lender receives the full benefit of the services, which means there is no reservation of rights with respect to them and the transfer is complete. On the other hand, in nearly all cases, the value of the services will be either de minimis (in the case of personal loans) or deductible as an ordinary business expense (in the case of business loans). ${ }^{121}$ For example, a homeowner's agreement with the mortgagee to maintain the property in good condition is unlikely to result in any conduct different from what she would have done without the mortgage. In the case of a business borrower, compliance with covenants may be both more substantial than in the personal loan setting and involve conduct that would not otherwise occur, but because undertaken as part of the regular conduct of the business, generally deductible under section $162 .{ }^{122}$

On the lender side, the fact that the benefit of the services provided is entirely business in nature justifies disregarding it for tax purposes. It is analogous to the benefit that a business owner receives for deductible services. ${ }^{123}$ In general, the owner has no inclusion on receipt of the services even though the payment was deductible. Instead, the inclusion happens on a later disposition of goods or services thereby financed, the cost of which does not include the amount paid for the deductible services. In the case of a borrower's execution of loan covenants or the provision of security, the lender obtains assurances that advance its business purposes but provide no personal benefit. Instead, the

\footnotetext{
${ }^{117}$ Borrower covenants are common features of lending transactions. Nada Mora, Lender Exposure and Effort in the Syndicated Loan Market, 82 J. RisK \& INS. 205, 208 (2015).

118 I.R.C. § 1001(a).

${ }^{119}$ Rev. Rul. 78-182, 1978-1 C.B. 265 (describing option rules). For deep-in-the-money options, see, e.g., Progressive Corp. \& Subsidiaries. v. U.S., 970 F.2d 188 (6th Cir. 1992).

${ }^{120}$ See, e.g., Rev. Rul. 55-540, 1955-2 C.B. 39, § 3.01 (discussing differences between leases and conditional sales and noting that in a genuine lease, incidents of ownership do not pass to the lessee).

${ }^{121}$ I.R.C. $\S 162(\mathrm{a})$.

${ }^{122}$ An exception would apply where the loan finances the production of identifiable property. See, e.g., I.R.C. $\S 263 \mathrm{~A}(\mathrm{a})(1)$ (requiring capitalization of certain otherwise deductible expenditures into basis or the cost of goods sold). In these cases, an inclusion on performance would occur but the cost typically would be recovered on later disposition of the property thereby financed. See I.R.C. § 1016(a)(1) (providing for adjustment to basis for, among other things, outlays "properly chargeable to capital account."

${ }^{123}$ See infra Part III.D for a discussion of the tax treatment of the receipt of deductible services.
} 
benefits show up in the greater profits the lender earns by reason of conducting its business properly. These profits are, of course, taxable. ${ }^{124}$

\section{Taxation of DOI}

Given that the borrower acquires no interest in the remainder when the loan is extended, the release of the borrower from repayment because it is uncollectible is a simple and straightforward accession to wealth: The borrower in effect appropriates the portion of the remainder that is canceled at the time of cancellation. No special theory, be it analogy to the TBR, the freeing of assets rationale, or the overall balance sheet rationale is necessary to explain why the debtor has income on cancellation. Assume Borrower borrowed $\$ 1,000$ from Lender in Year 1 on a recourse basis. Under the loan terms, interest only is due until Year 5, at which point the full principal is due. Borrower makes all interest payments as due until the first day of Year 3, at which point she defaults and Lender discharges the loan as uncollectible. The "remainder" here is simply the face amount of the principal, which at that point is economically transferred to Borrower. Lender has a corresponding loss equal to the face amount of the debt. There is no need to relate back to the date the loan was extended because the loan proceeds were not transferred to Borrower on that date. Rather, current use was transferred and it is the default that effectuates the transfer of the fee interest. That transfer is a simple accession to wealth for the borrower and a loss for the lender at the time of default.

Note that the treatment of the inclusion as a transfer in the year of default, rather than as a "relation back" to the year the loan was extended, avoids the difficulty under the standard view of accounting for interest payments on the forgiven amount. Recall that the standard view equates the default with a "hindsight" understanding of the original transfer as an accession to wealth when the loan was extended that must be accounted for in the year of discharge under the principle of transactional consistency. But such a theory cannot explain why the borrower paid interest before the default on the forgiven portion of the loan. It also violates the principle of transactional consistency because the tax benefit theory requires treating the forgiven amount as having been extended without a repayment obligation. Note also that under the tax benefit rationale there is no discount on the amount of the inclusion for the payment of interest; the inclusion is equal to the principal amount forgiven. ${ }^{125}$

It is worth noting that although LAL provides a straightforward account of DOI, it does not decisively resolve whether DOI should result in a taxable inclusion. Viewing the risk premium as a form of insurance highlights that either of two general regimes might apply to DOI income: a regime in which, on average, there is one inclusion, or a regime in which there may be two. In some settings, such as death benefits paid under life insurance contracts, the tax law excludes insurance payouts from gross income. ${ }^{126}$ In most such cases, the premiums must not have been deductible. ${ }^{127}$ In theory, the overall treatment of the insurance arrangement in these cases is a "nothing." Assuming a fair insurance scheme, in the case of term life insurance, premiums paid by all policyholders in the aggregate will

${ }^{124}$ I.R.C. $\S 61(\mathrm{a})(2)$.

125 Treas. Reg. § 1.61-12(a).

${ }^{126}$ I.R.C. $\S 101(a)$. See also I.R.C. $\S 104(a)(3)$ (exclusion for health insurance benefits as long as premiums are paid with after-tax dollars).

${ }^{127}$ I.R.C. § 264(a). An exception is employer-provided health insurance. Subject to certain premium limitations, premiums are deductible by the employer, I.R.C. $\$ 162(\mathrm{a})(1)$, and excluded from the employee's gross income, I.RC. § 106(a), while the amounts expended on medical care are excluded. I.R.C. § 105(b). 
equal payouts, less the cost of administering the scheme. Therefore, apart from the effect of graduated rates, it is a matter of indifference from a revenue perspective whether premiums are deductible and death benefits are includible, or premiums are nondeductible and death benefits are excluded. Under either approach, the death benefit is taxed once, either when the income to pay the premium is earned or when the death benefit is paid.

In other settings, such as payouts under property casualty insurance policies, the Internal Revenue Code treats recoveries as taxable to the extent of gain realized even if premiums are not deductible. ${ }^{128}$ Suppose Taxpayer insures her personal residence for its $\$ 300 \mathrm{k}$ fair market value, which exceeds her basis by $\$ 200 \mathrm{k}$. If the property is destroyed by a covered peril, $\$ 200 \mathrm{k}$ of the $\$ 300 \mathrm{k}$ recovery is taxable (though the gain may be deferred and even excluded under the special rules for gains realized on personal residences). ${ }^{129}$ This is so even though the premiums are not deductible. In this type of regime, both the premiums and what they pay for are subject to tax.

It is an open question as a policy matter which of these two regimes should apply. If one views the benefit of personal insurance as consisting solely of the payout, then the tax regime should be symmetrical: Premiums should be deductible if and only if recoveries are taxable. The argument for symmetry would be that the exclusive income benefit of the policy derives from the payout, while any peace of mind associated with having adequate insurance is akin to normally nontaxable surplus. In that case, the choice amounts to whether we tax insurance on an ex ante basis or an ex post basis. A deduction/inclusion regime taxes ex post; it treats the benefit of the insurance as speculative while the cost represents a reduction in consumable resources. A non-deduction/exclusion regime taxes ex ante; it treats the value of the right to proceeds as purchased up-front in the same way that life insurance is taxed. Whether ex ante or ex post, insurance payments are effectively taxed once.

If, however, one considers the privilege a risky borrower enjoys of using borrowed funds on analogy to the peace of mind associated with personal insurance to be a "purchased" income item separate from the benefit of any payout, then no deduction, or at best a partial deduction, should be available for the risk premium, and therefore income from DOI should be includible as well, subject to the exclusions and limitations available under section 108. LAL does not settle the question of which regime should apply because the answer turns on how expansively one views the income concept. If one considers income a proxy for utility - here, the utility of knowing the lender rather than the borrower experiences the loss - then a dual tax regime should apply. Under a more restrictive definition that sees income as consisting of a flow of material satisfactions, a single regime should likely apply. ${ }^{130}$

D. Irrelevance of Interest Deductibility

One might be persuaded of the validity of LAL but be tempted to conclude that the tax treatment of loans should turn on the deductibility of interest payments. The reasoning would be that LAL identifies the payment of interest as the basis for both non-inclusion and basis credit in the loan proceeds, and that conclusion rests, in turn, on the idea that

\footnotetext{
${ }^{128}$ See, e.g., I.R.C. $§ 1033($ a)(2) (treating amounts realized on involuntary conversions of property, which includes insurance proceeds, as taxable income unless invested in similar or related property). ${ }^{129} I d$.

${ }^{130}$ David Hasen, How Should Gifts Be Treated Under the Federal Income Tax?, 2018 Mich. STATE L. REV. 81, 83-84 (2018).
} 
interest payments represent a taxable purchase of liquidity. ${ }^{131}$ But if the interest is deductible, it appears the purchase is not made with after-tax dollars and the arguments for non-inclusion of loan proceeds and basis credit for them become weaker. Nevertheless, although plausible, the idea that treatment of the loan proceeds under LAL depends on whether the interest paid is deductible is incorrect for two related reasons. It mistakes the tax treatment of a deductible outlay with tax consequences that flow from a deductible outlay. More basically, it rests on a mistaken understanding of the reasons for business deductions and their effects on the taxpayer.

As a preliminary matter, it is helpful to clarify the stakes of the question. Recall that all that is purchased in any given period is the use of funds for that period. Periodic interest payments under a simple loan entitle the borrower to the use of the funds for those periods but not beyond them. Therefore, the question becomes whether there ought to be an inclusion or a denial of basis credit in the loan proceeds for that period if the associated interest payment is deductible. Further, if one concluded that an inclusion was appropriate, the amount would be equal to the value of the use of the loan proceeds for that period, which by definition is the interest paid, not the face amount of the loan. This amounts to arguing that no deduction should be available for interest. Stated otherwise, the argument for inclusion turns out to be that interest should never be deductible.

Begin with the consequences of the deductible payment itself. The receipt of goods or services in exchange for a deductible payment does not trigger income to the taxpayer. ${ }^{132}$ If it did, then the deduction itself would be pointless. For example, most salary is immediately deductible. ${ }^{133}$ It would defeat the deduction if the receipt of the service provider's services thereby purchased were taxable. Instead, the service recipient has no inclusion, but the cost of the services is not included in the cost of the goods or services thereby produced so that the deduction is recouped when they are sold.

This observation might in turn suggest that a taxpayer who deducts interest payments has a zero basis in the loan proceeds or in what is purchased with them, much as some have argued should be the case for loan proceeds generally. ${ }^{134}$ This analysis, however, rests on a mistaken view about the reason a deduction (or cost recovery more generally) for non-personal outlays is permitted in the first place. As discussed in Part II, a normative income tax reaches the individual's net change in wealth during the taxable period. ${ }^{135}$ Net change in wealth under the widely-accepted H-S income definition equals the sum of the change in explicit on-hand resources plus amounts spent on personal consumption. The inclusion of the latter in turn reflects the idea that personal consumption is merely the transformation of the thing consumed into some personal benefit to the consumer, or what is the same, that the voluntary aspect of the conversion of wealth into a consumption experience signals that the consumer is no worse off by reason of the expenditure. ${ }^{136}$ If two individuals each earn $\$ 100 \mathrm{k}$ of salary income during the taxable period but one of them spends $\$ 30 \mathrm{k}$ on consumption and the other $\$ 60 \mathrm{k}$, it is not

${ }^{131}$ See supra Part III.B.

132 The general rule for deductibility is set forth in section 162(a), which permits a deduction for ordinary and necessary business expenses.

${ }^{133}$ I.R.C. $\$ 162(\mathrm{a})(1)$. Business expenditures that create an identifiable asset of the taxpayer generally are not deductible; instead, the outlay is capitalized - added to the basis of the asset so created. I.R.C. $\S \S 263(\mathrm{a}), 263 \mathrm{~A}(\mathrm{a})$.

${ }^{134}$ See supra Part II.C.

135 See supra Part II.

${ }^{136}$ Andrews, supra note 75, at 1114. 
appropriate to treat them differently under an income tax. One has chosen to defer more consumption than the other, but that is not a reason to tax that person more heavily. ${ }^{137}$

Within this framework, outlays incurred to produce income enjoy separate treatment. Amounts expended on supplies, utilities, and related items to generate net positive incomes in the current taxable period are subtracted from income to avoid overstating, perhaps dramatically, the individual's true income during the period. ${ }^{138} \mathrm{An}$ obvious reason is that the outlay does not reflect the transformation of wealth into something of equal personal value but rather is motivated by business exigency as a means to create wealth that at some future point will be converted into consumption (whether by the individual or by someone else of her choice). As contrasted with a home utility bill, amounts paid for electricity to run the factory do not confer a contemporaneous personal benefit on the taxpayer, and they also are not available as a store of wealth that can be readily converted into a consumption experience. Thus, the assumption that a cash receipt is equivalent to the receipt of a personal benefit is defeated.

The absence of a personal benefit to business outlays does not mean that business outlays represent losses. ${ }^{139}$ Business expenses do not represent true losses; if they did, business owners would not voluntarily incur them. Instead, the deduction for business expenses implements a timing principle that is justified on the basis that, at best, the outlays represent an immediate reduction of consumable value but are expected in a future period to represent a gain. In this respect, deductions for business expenses (as contrasted with losses) simply reflect a presumption shift that is justified by the fact that the personal benefit they provide is speculative and mediated. The certainty of the lack of benefit now coupled with the speculative status of the benefit later (if the taxpayer is profitable) justifies allowing a provisional deduction now that is made good later by disallowing in the cost of goods sold basis resulting from deductible outlays. As contrasted with a personal outlay, the realization of a benefit requires the successful conversion of the outlay into an income item, and that conversion may never occur.

Consider that implementing the principle that an income tax reaches net changes in wealth in no way requires a deduction for business expenses. The same result, apart from timing differences, could be reached (and would more obviously and directly be reached) by denying a deduction and simply adding business outlays to the cost of goods sold. Indeed, this principle already applies to certain cases in which Congress views the availability of an immediate deduction as inappropriate on timing grounds, largely because the outlay results in the production of tangible goods that can be readily sold. ${ }^{140}$ Apart from a possible timing mismatch (since the goods thereby produced may be sold in a later period), the capitalization of costs method directly implements the idea that an income tax reaches the taxpayer's change in wealth during the period. When already-taxed dollars are

\footnotetext{
137 The point applies to the $\$ 100 \mathrm{k}$ earned in the period, not to returns that the saver may receive on amounts invested.

${ }^{138}$ The main provision in the Internal Revenue Code that ensures a deduction is section 162(a).

${ }^{139}$ See 7 Jacob Mertens, Mertens LaW of Fed. InC. TAX. ๆ 28:52 (2020) (discussing differences between and relationship of business expenses and business losses).

${ }^{140}$ Section 263A requires certain taxpayers to capitalize inventory and other costs in lieu of an otherwise available business deduction. Congress enacted section 263A in the Tax Reform Act of 1986. The Senate Finance Committee Report explains in relevant part: "[T] he existing rules may allow costs that are in reality costs of producing, acquiring, or carrying property to be deducted currently, rather than capitalized into the basis of the property and recovered when the property is sold or as it is used by the taxpayer. This produces a mismatching of expenses and the related income and an unwarranted deferral of taxes." S. REP. No. 99-313, at 92 (1986).
} 
spent in an arm's-length market transaction, no taxable income arises. Thus, a rule that capitalizes all costs, business and personal, but allows a loss deduction only for the sale of non-personal property would yield the same basic system that a business expense regime implements.

The lesson from all of this is that a true and final deduction is allowed only when the taxpayer sustains a loss. ${ }^{141}$ Deductions for business outlays are nothing more than a timing rule that reflects a presumption shift: A deduction is available now because the outlay itself categorically removes resources available to provide a personal benefit and only contingently makes resources available to make the current outlay good. Because amounts deducted as business expenses are not added to the cost of goods sold, the net effect is to recoup the loss (in whole or part) on sale of the associated business item.

These considerations indicate that full basis credit in the liquidity purchased should be available to the taxpayer regardless of whether interest is deductible as a business expense. Basis credit is appropriate in the business setting because the liquidity does not produce a personal benefit. Consider that if the interest were not deductible, it is clear both that (1) under LAL, basis credit in the liquidity would be available, and (2) interest expense would be added to the cost of goods sold in order to arrive at a true measure of income. ${ }^{142}$ As demonstrated in this Subpart, the difference between a regime that implements these two principles and one that permits a deduction for interest and denies any further cost recovery for interest expense represents an improvement in timing because of the absence of a personal benefit from the outlay itself.

\section{THE TAX TREATMENT OF PARTNERSHIP BORROWING}

One might consider the argument to this point largely academic since the three propositions discussed in Part II are mostly consistent with LAL anyway. Although I am not sanguine on the point given the potential that policy discourse has for upending settled rules, the consequences of adopting LAL go beyond academic debate because there are areas in which LAL has ramifications for existing law. This Part focuses on one such area, partnership tax accounting.

When a partnership borrows, the partnership receives basis credit in the loan proceeds just as any other borrower does, but the question arises of how to allocate the basis credit among the partners. ${ }^{143}$ Suppose that $A B$ 's two partners, $A$ and $B$, share all items of partnership income, gain, loss, and deduction (IGLD) in a 60:40 ratio. Each partner has a basis in her interest in $A B$ that reflects her after-tax investment in it. ${ }^{144}$ If $A B$ borrows cash from a third-party lender and uses the proceeds to purchase business property, $A B$ will

${ }^{141}$ I.R.C. $§ 165$. Section 165 implements the deduction for losses. Although the 2017 tax reform act temporarily disallows deductions for most personal losses, see $\S 165(\mathrm{~h})(5)$, the provision is controversial in that it appears to be a departure from a normative income tax. See, e.g., Jeffrey H. Kahn, The Misconstruction of the Deductions for Business and Personal Casualty Losses, 21 Fla. TAx REV. 621, 630 (2018).

${ }^{142}$ See, e.g., $\S 263 \mathrm{~A}(\mathrm{f})$, which permits capitalization of interest payments for interest, the deduction for which is denied under section $263 \mathrm{~A}(\mathrm{a})$.

${ }^{143}$ I.R.C. $\S 752$. The question does not arise for "C" corporations because, as contrasted with partnerships, C corporations are taxpayers. I.R.C. $\S 11$. Accordingly, the corporation functions analogously to an individual for this purpose. Partnerships are subject to a pass-through regime under which the partnership's items of IGLD are taxable to the partners only. I.R.C. § 701. The problem for borrowing also would arise, in theory, for $\mathrm{S}$ corporations, which like partnerships are pass-through entities, except that $\mathrm{S}$ corporation shareholders do not receive basis credit in the corporation's debt unless the shareholder is the lender. I.R.C. § 1367(b)(2)(A).

${ }^{144}$ I.R.C. $\S 722$. 
have basis in the property in the same way that any other borrower would, ${ }^{145}$ but it is not obvious how the basis credit will be shared between $A$ and $B$ in their partnership interests. Does it go to them equally, or on the basis of their interests in $A B$, or according to some other principle? Basis allocation is important for a number of reasons, including the availability to the partners of deductions allocable to them from the partnership's activity ${ }^{146}$ and the partners' ability to avoid inclusions on cash distributions from the partnership to them. ${ }^{147}$ As a general matter, deductions are available, and income inclusion avoided, only to the extent of the partner's basis in her partnership interest, with deductions and cash distributions reducing basis dollar for dollar (not below 0). ${ }^{148}$ Allocable deductions that exceed available outside basis are suspended and carried forward, ${ }^{149}$ while cash distributions in excess of available outside basis are taxable. ${ }^{150}$

Under current regulations, the method of allocating basis credit for partnership borrowing among the partners depends on the nature of the borrowing. If the loan is recourse to one or more partners, basis is allocated by "economic risk of loss" (ERL). ${ }^{151}$ If it is nonrecourse, a more complicated regime applies, but for present purposes it will suffice to treat the basic rule as allocation by profit shares. ${ }^{152}$

As developed below, LAL is flatly inconsistent with making allocations according to ERL and is in some tension with making allocations by profit shares. If the rules were reformed to reflect the principle that interest is the consideration paid for the use of loan proceeds, the rules for partnership liabilities would not be bifurcated based on the nature of the debt as recourse or nonrecourse. Instead, the rules would be uniform and would in some measure parallel the existing rules for what are termed "excess nonrecourse liabilities." "153 This is an especially attractive result given the functional similarity between most (genuine) nonrecourse and recourse debt. By contrast, under current law, partners can effectively choose basis allocations to a large extent by structuring a loan as recourse or nonrecourse, depending on which best suits their tax preferences, even though the facts on the ground may differ only slightly between the two arrangements.

A. Recourse Liabilities

Applicable regulations define recourse liabilities of a partnership as liabilities for which one or more partners or related parties would be personally liable on default. ${ }^{154}$ The

${ }^{145}$ I.R.C. $§ 752$ (a) (provides that a partner's assumption of a partnership's liability is treated for all purposes as a cash contribution by the partner to the partnership). I.R.C. $\S 723$ (provides that the partnership's basis in property includes that of the contributing partner, meaning that the partner gets basis credit in the cash deemed contributed under section 752). Section 752 does not specify, however, how to determine the size of the deemed cash contribution of any individual partner in respect of the partnership's third-party borrowing. Instead, regulations under section 752 provide rules as discussed in this subpart. See Treas. Reg. §§ 1.752-1 (treatment of partnership liabilities in general), -2 (treatment of partnership recourse liabilities), -3 (treatment of partnership nonrecourse liabilities).

${ }^{146}$ I.R.C. $\S 704(d)(1)$.

${ }^{147}$ I.R.C. $\$ 731(\mathrm{a})(1)$.

148 I.R.C. $§ 705(\mathrm{a})(2),(3)$.

149 I.R.C. $§ 704(d)(2)$.

${ }^{150}$ Id. Section 705(a) provides that distributions reduce basis before deductions do.

151 Treas. Reg. $\$ 1.752-2(\mathrm{a})$.

152 Treas. Reg. $\S 1.752-3(a)(3)$. Special rules apply to "partnership minimum gain" and gain that would be allocable under the principles of section 704(c) to a partner that contributes property subject to a nonrecourse obligation in excess of basis. Treas. Reg. $\S \S 1.752-3(a)(1),(2)$.

153 Treas. Reg. $§ 1.752-3(a)(3)$.

154 Treas. Reg. § 1.752-1(a)(1). 
ERL principle assigns basis credit for the partnership's recourse borrowing by determining which partner(s) would be personally liable to repay the loan if it immediately became due in full and essentially all of the partnership's assets, including cash, simultaneously became worthless. ${ }^{155}$ (This is sometimes referred to as the "catastrophe theory.") The ERL procedure operationalizes the idea that the main liability that is incurred in a loan transaction is the obligation to repay principal. ${ }^{156}$ Assume that $P R S$, a general partnership, borrows $\$ 3,000$ from Bank. PRS has three partners, $A, B$, and $C$. Pursuant to state law, the partners are equally liable for the partnership's debts, but under PRS's operating agreement, $C$ promises to reimburse $A$ and $B$ for two-thirds of what they might be called upon to pay under state law to satisfy the loan. Under the ERL regulations, basis in the loan proceeds would be allocated $\$ 333$ to each of $A$ and $B$ and $\$ 2,333$ to $C$ as long as the allocation was not made for an illicit tax avoidance purpose. ${ }^{157}$ Apart from any such purpose, the allocation takes no cognizance of who bears the real economic cost of the loan. Imagine, for example, that $C$ contributes capital to the partnership and $A$ and $B$ contribute their services, with the parties' dividing their interests in profits and losses 40 percent to each of $A$ and $B$ and 20 percent to $C$. Beyond that division of income and loss, assume that $P R S$ makes no special allocations of its items of IGLD. ${ }^{158}$ Under the ERL analysis, the 20 percent partner receives more than three-quarters of the basis credit in the loan, even though she economically bears just 20 percent of its cost assuming it is paid according to its terms (as will ordinarily be the case under a genuine loan).

Two features of the ERL regulations tacitly acknowledge the unreality of the ERL test. First, the regulations assume that as long as there is no illicit tax avoidance to the allocation of liability in the catastrophe scenario, all partners are assumed able to satisfy the liabilities to which they would be subject if the catastrophe actually happened, regardless of whether it would be realistic to assume so in light of their actual financial positions. ${ }^{159}$ This rule makes perfect sense given that no one typically expects the burden of the loan to be shared in this way (that is, no one expects the catastrophe that the regulations posit is likely to happen), but that expectation in turn simply highlights that ERL is unmoored to economic reality. In effect, the rule says that even though commercially reasonable parties would not expect the obligation to be satisfied in the manner prescribed by the ERL analysis, they are to assume counterfactually that it would be for the purpose of assigning basis credit.

155 Treas. Reg. § 1.752-2(b). An exception applies to existing nonrecourse debt of the partnership, which is treated as satisfied at face amount. Treas. Reg. $\S \S 1.752-2(b)(1)(i i),-2(b)(2)(i)$.

${ }^{156}$ See, e.g., William S. McKeE, William F. Nelson \& Robert L. Whitmire, Federal Taxation OF PARTNERSHIPS AND PARTNERS $\uparrow$ 8.02[2] (2021) ("The only time a partner will be called upon to come out of pocket with respect to a partnership liability is when the partnership is unable to pay all or a portion of that liability. Thus, any examination of the partners' obligations at a time when the partnership's assets have value would necessarily produce an artificial and potentially skewed analysis as to how the partners bear the economic risk of loss. By crediting partners with outside basis attributable to a liability to the extent the partners would be obligated to make payments in the event of a total loss of value in the partnership's assets, the $\S 752$ Regulations duplicate the consequences of the worst-case hypothetical situation.").

${ }^{157}$ Treas. Reg. $\S 1.752-2(\mathrm{~b})(6)$. That is, under the ERL procedure, each partner pays $\$ 1,000$, but $C$ then reimburses $A$ and $B \$ 667$ each.

${ }^{158}$ Treas. Reg. § 1.704-1(b)(2). Assume further that the allocation qualifies as having "substantial economic effect" under the applicable regulations so that it is respected for tax purposes.

159 Treas. Reg. § 1.752-2(b)(6). 
Secondly, the ERL regulations adopt special treatment for "bottom-dollar payment obligations" (BDPOs). ${ }^{160}$ Very generally, a partner's obligation with respect to a partnership's liability is a BDPO if the partner is required to make good on default only to the extent in excess of one or more other partners' obligations. Suppose that in the PRS example, the partners had agreed that $A$ and $B$ each would be equally and exclusively liable on the first $\$ 400$ of partnership debt in the event of default, while $C$ would be liable only to the extent that Bank otherwise recovers less than $\$ 600$. C's obligation is a BDPO. Under the BDPO rules, $C$ 's nominal obligation is disregarded for the purpose of determining ERL. Instead, the basis that would have been allocated to $C$ is reallocated among the partners under the rules that apply to the allocation of basis for nonrecourse liabilities of the partnership. ${ }^{161}$

Like the ERL rules, the BDPO exception to ERL reflects an acknowledgment that allocation of basis credit by liability under the catastrophe theory is in many ways unrealistic. In fact, its realism depends on an assumed proportionality of what would happen under the catastrophe and what would happen under more realistic scenarios. For example, if each partner is liable for one-third of the debt, loss is allocated the same way for a default of ten percent and a catastrophic loss. But to the extent that the regulations effectively depend on this approach, the catastrophe rule is neither needed nor appropriate.

The BDPO rules address one potential abuse available under the ERL procedure, but not all of them. Consider that the partners may well be willing to make special allocations of risk of loss that do not qualify as BDPOs but that dramatically alter their obligations in the case of default. The partners may be willing to do this because they know that the risk of default is slim (and may even be insurable by a partner through an arrangement with an outside party) so that a minor economic cost yields a substantial tax benefit. The result is tax-motivated basis shifts that have little nontax significance. Suppose the three partners of equal $X Y Z$ are largely indifferent on a pretax basis between an allocation of ERL with respect to a loan equally among themselves, or 10 percent to each of $X$ and $Y$ and 80 percent to $Z$. They may be willing to allocate ERL in this manner because they know that default requiring the partners to make a payment is very unlikely. Possible reasons could be that the security $X Y Z$ provides for the debt may have a value well in excess of the loan amount, or the partnership may have a sufficiently stable income stream to make default unlikely in the first place. By adjusting the formal risk of loss to $Z$, she secures additional basis credit at little or no economic cost. ${ }^{162}$

B. Nonrecourse Liabilities

The unreality of the ERL analysis emerges most pointedly when compared to the rules for allocation of basis in partnership nonrecourse debt. Suppose instead that the loan in our PRS example is nonrecourse. Because the partnership has no obligation to repay the debt, ERL is said to remain with the lender. ${ }^{163}$ Allocation of basis according to ERL is therefore impossible if nonrecourse debt is going to be treated the same as recourse debt

${ }^{160}$ Treas. Reg. $§ 1.752-2(\mathrm{~b})(3)(\mathrm{ii})$.

161 See Treas. Reg. § 1.752-2(f), Ex. 10.

162 Treas. Reg. $\$ 1.752-2(\mathrm{~b})(1)$.

${ }^{163}$ See, e.g., Comm'r v. Tufts, 461 U.S. 300, 312-13 (1983) (stating that mortgagee remains at risk with respect to the security for the loan). 
for tax purposes. A long line of authority has consistently treated NRD the same as recourse debt, ${ }^{164}$ and the partnership rules sensibly adopt the same treatment. ${ }^{165}$

To maintain parity with the treatment of debt outside the partnership setting, the partnership nonrecourse debt regulations generally allocate basis among the partners under a complicated three-tiered waterfall provision that in some respects tracks the principles for recourse debt but in others departs from those principles materially. ${ }^{166}$ Because the first two tiers to some extent embody the principles for recourse debt, they also embody the problems identified above. Rather than enter into an extended discussion of the nuances of these technical provisions, suffice it to say that the basic problems with them are similar to those for recourse debt.

The third tier, by contrast, sets forth a principle in some ways closely aligned to LAL. It applies to "excess nonrecourse liabilities," defined as nonrecourse liabilities not covered under the first or second tier. ${ }^{167}$ Excess nonrecourse liabilities are allocated among the partners in proportion to the partners' shares of partnership profits (the "partnership profits rule" or PPR). ${ }^{168}$ Notably, the PPR will often end up allocating basis credit in accordance with who bears the economic burden of the interest payments. The basic PPR provides that a partner's interest in profits depends on all the facts and circumstances, ${ }^{169}$ but in a simple partnership, in which all items of IGLD are allocated ratably based on capital invested, profits and interest expense will mirror each other so that a profits rule is a perfect substitute for allocation by who economically bears interest expense. Even in a more complicated arrangement or one that expressly allocates interest deductions differently from the allocation of profits, a basis rule tied to profits will often yield a reasonable result under LAL because profit shares tend to reflect the partners' real expense burden, including interest expense. As an illustration, suppose $X Y Z$ 's three partners each contribute $\$ 100 \mathrm{x}$ in exchange for an interest in the partnership, and $X Y Z$ then borrows $\$ 200 x$ from Bank on a nonrecourse basis, using the property purchased with the loan as security for it. Suppose further that the $X Y Z$ partnership agreement validly assigns all interest deductions to $Z$ and otherwise complies with the rules for substantial economic effect. $^{170}$ If the partners are dealing with each other at arm's length, the overall computation of profits should nevertheless account for the net costs of each partner, so that in substance, the partners share interest expense in proportion to profit shares, even though as a matter of partnership accounting the interest is "paid" by $Z$.

Beyond a general rule of assigning basis credit by profit shares under all of the facts and circumstances, the PPR contains three safe harbors that deem an assignment to be in accordance with the rule. Assignments under the first safe harbor may tend to result in allocations that are the same as, or reasonably close to, an explicit allocation of basis in accordance with LAL, but allocations under the second and third will not. ${ }^{171}$ Under the

${ }^{164}$ See, e.g., Crane v. Comm'r, 331 U.S. 1 (1947). (nonrecourse debt provides basis to borrower); Tufts, 461 U.S. 300 (1983) (same under the TBR rationale); Woodsam Assoc., Inc. v. Comm'r, 198 F.2d 357 (2nd Cir. 1952) (extension of nonrecourse debt not treated as a sale); Treas. Reg. § 1.1012-1(g)(1) (cost of property includes issue price of debt instrument exchanged therefor).

165 Treas. Reg. \$ 1.752-3.

166 Treas. Reg. § 1.752-3(a).

${ }^{167} \mathrm{Id}$.

${ }^{168} I d$.

${ }^{169} \mathrm{Id}$.

170 Treas. Reg. § 1.704-1(b)(2).

171 Treas. Reg. § 1.752-3(a)(3). 
first, nonrecourse debt basis allocations that track allocations of partnership income or gain that themselves have substantial economic effect will be respected. Suppose that the $P R S$ operating agreement validly allocates all items of $P R S$ 's IGLD in respect of Asset 1 to $P$. Suppose further that $P R S$ initially financed Asset 1 with partnership capital but later pledged Asset 1 as security for nonrecourse debt. $P R S$ 's operating agreement could validly allocate the basis credit for the loan solely to $P$. This allocation would comport with LAL because $P$ would bear the burden of the interest expense as an item of deduction already allocated to $P$.

The remaining safe harbors under the PPR are less consistent with LAL. A detailed analysis of them would involve an excursion into the arcana of partnership tax, but it suffices to note that the second and third safe harbors tend to produce allocations that mimic the ERL rules to some extent and therefore are problematic for the same reasons. ${ }^{172}$

\section{Partnership Borrowing Under LAL}

For the reasons developed in Part III, the identity of the bearer of risk of loss under the loan should not be relevant to the question of who gets basis credit. Because a loan is fundamentally an exchange of interest for the use of funds and, in most cases, an additional payment for insurance, the person who economically bears the interest and insurance cost should get basis credit, regardless of whose liability is discharged on nonpayment. By contrast, the existing partnership tax rules depend critically on the threshold determination of whether the loan is recourse or not to the partnership.

The fact that the parties to a loan agreement often need do very little to adjust its terms between recourse and nonrecourse corroborates the point that the existing rules are incorrect. A shift from recourse to nonrecourse may require a slightly higher interest rate, a slightly better security, somewhat greater monitoring of the borrower's use of the security, or other relatively minor adjustments to the loan terms. Because the tax difference between the two types of loans when a partnership is the borrower is substantial, the rules provide untoward tax planning opportunities. Consider the difference in tax treatment between two alternative $\$ 500 \mathrm{x}$ loans that equal $A B C$ might take, using Whiteacre as security. Whiteacre's fair market value is $\$ 1000 \mathrm{x}$ and its basis in $A B C$ 's hands is $\$ 200 \mathrm{x}$. Assume that $A B C$ runs a successful business and its annual income does not fluctuate greatly; it also has no other nonrecourse debt outstanding. The loans are identical except that in one scenario it is recourse and in the other it is nonrecourse. If the loan is recourse, the partners might agree to allocate the ERL largely to one of the partners, even though that partner otherwise shares equally in the partnership's items of IGLD. ${ }^{173}$ If, however, the loan were nonrecourse, then the entire nonrecourse liability would qualify as an excess nonrecourse liability and, assuming the basic facts and circumstances test applied, divided equally. ${ }^{174}$

A rule for all partnership debt that mirrored the basic rule for excess nonrecourse liabilities and the first safe harbor (but not the remaining safe harbors) would be a reasonably effective means of allocating basis credit among the partners, regardless of

${ }^{172}$ Id. The second PPR safe harbor permits an allocation of basis credit for excess nonrecourse liabilities in accordance with a valid allocation of "nonrecourse deductions," while the third safe harbor permits an allocation of basis credit in accordance with how gain would be charged to a partner on the disposition of the property in satisfaction of the debt. $I d$. Both of these methods adopt a principle that links basis credit to income on debt discharge rather than to who pays for liquidity.

173 Treas. Reg. $§ 1.752-2(b)(1)$.

174 Treas. Reg. § 1.752-3(a). 
whether the debt is recourse or not. It also would provide partners the flexibility that is a hallmark of the partnership tax rules more generally. ${ }^{175}$ As a general matter, that flexibility extends to most allocations of partnership items of IGLD as long as they have substantial economic effect. ${ }^{176}$ The basic "facts and circumstances" rule for determining a partner's share of partnership profits looks to the economic substance of the partners' deal, which, as noted, would generally allocate basis credit in accordance with the economic burden of interest deductions regardless of how they are formally allocated. Although the facts and circumstances test would not itself provide flexibility, the first safe harbor, known as the "significant item method," would, and it would do so in a way that ties the allocation to profits or gains associated with the borrowing.

\section{V. $\quad$ NOTE ON THE HAIG-SIMONS DEFINITION OF INCOME}

At the outset I noted that LAL has implications for larger policy questions as well. ${ }^{177}$ This Part briefly discusses one of them, the nature of the relationship between income and consumption taxation, an area that has received sustained attention in the tax policy literature. ${ }^{178}$

To review, the H-S definition provides that income during the period equals the sum of the taxpayer's change in wealth (positive or negative) and the market value of amounts consumed:

$$
\mathrm{I}=\Delta \mathrm{W}+\mathrm{C} .^{179}
$$

As noted previously, the inclusion of the dollar value of amounts consumed ensures that the tax base reaches net changes in wealth, regardless of whether the wealth is retained or converted into a consumption of value equal to the income that purchased it. ${ }^{180}$ A taxpayer who during the period earns $\$ 100,000$ of salary and spends $\$ 30,000$ of it on consumption, saving the balance, has the same income as one who earns the same salary but spends $\$ 40,000$.

It is sometimes said that the practical difference between the two bases boils down to the deductibility of amounts invested, an observation that is suggested by the H-S definition itself. ${ }^{181}$ If income equals change in wealth plus amounts consumed, consumption equals income less a deduction for amounts saved. In fact, William Andrews famously argued for a simpler and, in his view, fairer cash-flow consumption tax on this basis. ${ }^{182}$ Andrews observed that, given the capacity of the tax system to compute $I$, one

${ }^{175}$ MCKeE, Nelson \& WhitMIRE, supra note 156, \1.03 (“One of the principal legislative objectives of Subchapter K was to afford partners 'flexibility' in allocating the tax burden of partnership transactions among themselves." (citation omitted)).

176 Treas. Reg. $§ 1.704-1(b)(2)$

177 See supra text accompanying notes 19-20.

178 See Daniel N. Shaviro, Special Report: Replacing the Income Tax with a Progressive Consumption Tax, TAX Notes 91, 92 (April 5, 2004) ("The literature on income versus consumption taxation could fill many rows of library shelves ...").

${ }^{179}$ See SimONS, supra note 28, at 50.

${ }^{180}$ See Stanley A. Koppelman, Personal Deductions Under an Ideal Income Tax, 43 TAx L. Rev. 679, 684-85 (1988).

${ }^{181}$ Joseph Bankman \& David A. Weisbach, The Superiority of a Consumption Tax over an Income Tax, 58 StAn. L REV. 1413, 1417 (2006) ("As is well known, the difference between an income tax and a consumption tax is the taxation of the return to savings or capital income. In a consumption tax, the risk-free return to investing is exempt, while in an income tax, the return is taxed."); Edward J. McCaffery, The Uneasy Case for Capital Taxation, 23 Soc. PHIL. \& POL'Y. 166 (Summer 2006).

182 Andrews, supra note 75. 
simply needed to solve for $C$ to adopt a cash-flow tax. In the example above, the two taxpayers would not have identical taxable amounts under a cash-flow consumption tax. The first would be taxed on $\$ 30,000$ of consumption, while the second on $\$ 40,000 .{ }^{183}$

The position developed in this Article, that a normative income tax does not include loan proceeds in the base, highlights an equivocation in the treatment of debt under Andrews's cash-flow model, albeit one that he recognized. ${ }^{184}$ Suppose Taxpayer $T$ earns $\$ 100,000$ during the period and, separately, borrows $\$ 300,000$ for an extravagant roundthe-world trip for herself and her family, all of which is spent in the same year. A true cash-flow tax puts $T$ 's consumption at $\$ 400,000$ (disregarding the treatment of interest on the loan), whereas an income tax disregards the loan proceeds. Two points follow. First, the inclusion of consumption in the H-S income definition should be understood as a kind of backstop; it is not so much part of the definition of income as a concession to the periodic nature of the tax. In calculating income, one cannot simply compare wealth on hand at the end of the taxable period to wealth at the end of the previous period because some, perhaps much, of the wealth received during the period may have been transformed into psychological satisfactions that would otherwise disappear from the base if consumption were disregarded. But if the tax were calculated on a continuous rather than a periodic basis, the inclusion of consumption would be unnecessary because the income that funded it would have been included on receipt. ${ }^{185}$ In other words, an income tax is really an accessions tax, where accession is understood as the receipt of value in excess of alreadytaxed amounts against which there is no claim. Consumption, therefore, is not a proxy for income, because consumption can be financed with amounts against which others do have a claim, such as when consumption is debt-financed.

Secondly, and more importantly, the denial of an inclusion for amounts spent on debt-financed consumption does not extend to the algebraic derivation of a cash-flow consumption tax from the H-S income definition. That is, the (technically) proper definition of a cash-flow tax as $C=I-\Delta W$ applies only if $I$ includes loan proceeds. If $I$ does not include loan proceeds, then the tax is no longer a cash-flow tax. But if $I$ includes loan proceeds, it is not a genuine income tax, for the reasons developed at length in this Article.

These observations do not defeat the general result that in their pure forms, a cashflow consumption tax and an income tax differ only in their treatment of the tax on the return to waiting. ${ }^{186}$ An income tax burdens that return while a cash-flow tax does not. But they do highlight the substantial differences between the bases in their operational forms, which of necessity are periodic. Consumption is not a proxy for income (or wealth), which means that large taxes may be due under a consumption tax from a taxpayer who has little (or even negative) wealth during the period, and vice-versa. A cash-flow consumption tax is really a tax on a flow of satisfactions to the taxpayer, regardless of

${ }^{183} \mathrm{Id}$. at 1120.

${ }^{184}$ See id. at 1154-55. Andrews recognizes that a true cash-flow tax would include loan proceeds in income with a deduction if spent on investment but none if spent on consumption. At the back end, all loan repayments would be deductible. To avoid the problem of a large inclusion on receipt of consumer debt, he proposes instead simply disregarding the loan, which in most cases would result in a decent approximation of a consumption tax since most large consumption outlays finance consumption through a number of periods, unlike the example in the text.

${ }^{185}$ For the operation of such a tax, see Jeff Strnad, Taxing New Financial Products: A Conceptual Framework, 46 StAN. L. REV. 569 (1994).

${ }^{186}$ Bankman \& Weisbach, supra note 181, at 1417. 
whether the taxpayer has a final economic right to them. An income tax reaches only amounts "cleared" of others' economic claims, regardless of whether the amounts are directed to a flow of satisfactions to the taxpayer in the period earned or in a later period.

\section{CONCLUSION}

Debt is, in many ways, a less complicated arrangement than income tax scholarship has made it out to be. It is a simple value-for-value exchange, in most cases nontaxable to the parties involved for reasons that follow in a straightforward way from the definition of income as an accession to wealth and the nature of what is exchanged in the transaction. Further, cancellation of debt triggers income to the borrower (and a deduction to the lender) for reasons having nothing to do with a retroactive tax benefit rationale but simply because an item formerly not part of the borrower's income - the "remainder" in the cash lentbecomes part of the income in the period of cancellation.

Viewing loans in this way, as an exchange of interest for liquidity, does have consequences for existing law beyond shoring up the rules that apply in most settings. Because the tax law treats a partnership's borrowing as borrowing by the individual partners, it becomes necessary to allocate basis credit among them in some manner. Under LAL, it is clear that basis should be allocated to each partner based on the extent to which the partner bears the economic burden of paying for the liquidity. Existing rules for recourse debt do not follow that principle, while some of the rules for nonrecourse debt come close. A modification to the tax rules that treats all partnership debt-recourse or nonrecourse - under LAL would both allocate basis credit properly and remove a significant discontinuity in the tax law. 